\title{
Interactions of the Oct-1 POU subdomains with specific DNA sequences and with the HSV $\alpha$-trans-activator protein
}

\author{
Thomas M. Kristie and Phillip A. Sharp \\ Center for Cancer Research and Department of Biology, Massachusetts Institute of Technology, Cambridge, Massachusetts \\ 02139 USA
}

\begin{abstract}
Trans-activation by the herpes simplex virus (HSV) protein, $\alpha$ TIF (VP16), is dependent on an inducible enhancer sequence that contains a homolog of the octamer element. An ordered series of multiprotein complexes can be assembled on this enhancer, requiring the interactions of Oct-1, $\alpha$ TIF, and two additional cellular factors (C1 and $\mathrm{C} 2$ ). Oct-1 binds to the octamer homolog, whereas $\alpha \mathrm{TIF}$, also a sequence-specific DNA-binding protein, recognizes sequences within the HSV enhancer core. The partially purified $\mathrm{Cl}$ factor interacts directly with

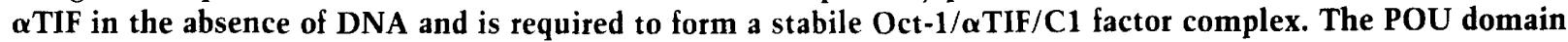
of Oct-1 is a bipartite sequence recognition structure, as both the POU-specific box and the POU homeo box contribute directly to the recognition of the octamer element. Surprisingly, the POU homeo box alone is sufficient to direct the cooperative binding of $\alpha$ TIF and to assemble the Oct-1/ $\alpha \mathrm{TIF} / \mathrm{C} 1$ factor complex.
\end{abstract}

[Key Words: Herpes simplex virus; octamer-binding proteins; protein-protein interactions; homeo box; POU domain; POU-specific box; protein-affinity chromatography; cooperative DNA binding]

Received September 27, 1990; revised version accepted October 24, 1990.

The diverse transcriptional regulatory events involved in the determination of cell type or development often appear to be mediated by the recognition of common DNA elements. Thus, the required specificities in such a program may rely on a combination of particular sites and the assembly of multiple factors. The regulation mediated by the common octamer element $\left(5^{\prime}\right.$-ATGCAAAT- $\left.3^{\prime}\right)$ is a model system for the analysis of such interactions.

The octamer element is recognized by at least three sequence-specific DNA-binding proteins (Singh et al. 1986; Staudt et al. 1986; Schreiber at al. 1988; Lenardo et al. 1989; Scholer et al. 1989a). Oct-1 is constitutively expressed in many mammalian cell types, whereas Oct-2 and Oct- 4 are expressed primarily in lymphoid and embryonic cells, respectively (Singh et al. 1986; Staudt et al. 1986; He et al. 1989; Scholer et al. 1989a,b). Members of the POU family, these trans-activators share a conserved domain (POU domain) that has been subdivided into two regions termed the POU-specific box and the POU homeo box (Clerc et al. 1988; Herr et al. 1988; Ko et al. 1988; Sturm et al. 1988/. Collectively, these regions are responsible for the high-affinity, sequence-specific binding to the octamer element (Sturm and Herr 1988; Garcia-Blanco et al. 1989). The POU homeo box region contains the helix-turn-helix motif characteristic of the homeo box family and is hypothesized to be the primary determinant in the recognition of the octamer element (Laughon and Scott 1984; McGinnis et al. 1984; Clerc et al. 1988; Jordan and Pabo 1988; Ko et al. 1988; Otting et al. 1988; Sturm et al. 1988; Qian et al. 1989; Scott et al. 1989|. The most highly conserved region, the POU-specific box, appears to contribute to the DNA-binding specificity of the protein and may also play a role in the cooperative interactions that arc exhibited by the intact POU domain (Sturm and Herr 1988; LeBowitz et al. 1989; Poellinger et al. 1989; Ingraham et al 1990).

Although Oct- 1 and Oct- 2 recognize the octamer element in an apparently identical manner (Staudt et al. 1986), they have been implicated in a wide range of regulation, including the constitutive expression of snRNA genes (Ares et al. 1987; Bark et al. 1987; Carbon et al. 1987; Murphy et al. 1987), the cell cycle-dependent expression of the histone H2B (Sive et al. 1986; Fletcher et al. 1987; LaBella et al. 1988), the cell-specific expression of immunoglobulins (Mizushima-Sugano and Roeder 1986; Staudt et al. 1986; Scheidereit et al. 1987; Wirth et al. 1987; LeBowitz et al. 1988; Muller et al. 1988b; Gerster et al. 1990; Muller-Immergluck et al. 1990), and the stimulation of adenovirus DNA replication (Pruijn et al. 1986, 1987; O'Neill and Kelly 1988; Verrijzer et al. 1990). The regulation of such diverse processes by these proteins can be modeled by their interaction with other 
specificity determinants such as the herpes simplex virus (HSV) $\alpha$-trans-induction factor $(\alpha \mathrm{TIF})$.

$\alpha$ TIF (also referred to as VP16, ICP25, and VMW65) is a $53-\mathrm{kD}$ protein, encoded by HSV and packaged within the tegument structure of the virion (Roizman and Furlong 1974; Batterson and Roizman 1983). Upon infection, the virion protein is released into the cell and induces the transcription of the five viral $\alpha$ or immediate early (IE) genes (Post et al. 1981; Campbell et al. 1984; Pellett et al. 1985). This regulation is dependent on specific enhancer elements in the regulatory domains of the $\alpha$ genes that contain a homolog of the octamer sequence (5'-GyATGnTAATGArATTCyTTGnGGG-3') and a highly conserved core element (TAATGArAT) (Mackem and Roizman 1982a-c; Kristie and Roizman 1984; Gaffney et al. 1985; Bzik and Preston 1986; for review, see McKnight et al. 1986; Pruijn et al. 1986). Analysis by electrophoresis in native gels has shown that $\alpha$ TIF could be assembled into specific multiprotein-DNA complexes, dependent on both the octamer and the HSV-specific core sequences of the $\alpha /$ IE element (McKnight et al. 1987; Gerster and Roeder 1988; O'Hare and Goding 1988; Preston et al. 1988; Kristie et al. 1989; Stern et al. 1989). The assembly of $\alpha$ TIF into these complexes required either Oct-1 or Oct-2, in addition to several discrete cellular components (McKnight et al. 1987; Gerster and Roeder 1988; Kristie and Roizman 1988; Kristie et al. 1989; Stern et al. 1989). Although these interactions depend solely on the highly conserved POU domain, Oct-1 has a 100-fold greater potential than Oct-2 to form these complexes (Kristie et al. 1989). Thus, this system provides an excellent model for the assembly of specific multiprotein complexes involved in the regulation processes that are mediated by the Oct proteins.

\section{Results}

Cellular factors required for the assembly of the aTIFdependent multiprotein-DNA complexes

Previous studies have demonstrated that a succession of protein-DNA complexes could be assembled in a stepwise manner on the $\alpha / \mathrm{IE}$ element (Kristie et al. 1989). The simplest DNA-protein complex was formed by the binding of Oct-l to the octamer homolog in the $5^{\prime}$ domain of this site. This complex was assembled into the slower migrating $\mathrm{Cl}$ complex by the addition of a crude S100 extract from cells infected with a recombinant baculovirus that overexpressed the $\alpha$ TIF protein. However, partial purification of $\alpha$ TIF from these extracts suggested that the S100 extract supplied an additional factor, the $\mathrm{Cl}$ factor, which was required to assimilate $\alpha$ TIF into the $\mathrm{Cl}$ complex. Comparison of the metal ion cleavage patterns of the Oct- 1 and $\mathrm{Cl}$ complexes showed that the former protected the octamer homolog while the latter protected the entire $\alpha / \mathrm{IE}$ element. An additional complex, the C2 complex, was formed when a nuclear extract of HeLa cells was added to the reaction containing Oct- 1 and $\alpha$ TIF. Therefore, a fourth component was hypothesized to bind to the $\mathrm{Cl}$ complex, resulting in the $\mathrm{C} 2$ complex. This complex did not alter the footprint of the $\mathrm{Cl}$ complex, suggesting that the $\mathrm{C} 2$ factor associated with the $\mathrm{Cl}$ complex primarily via protein-protein interactions.

A definitive assay for the analysis and characterization of the cellular components in these multiprotein complexes required purified $\alpha$ TIF and Oct- 1 POU domain proteins. Therefore, these proteins were expressed in Escherichia coli. Because the trans-activation domain of a TIF (carboxy-terminal, amino acids 413-490; Triezenberg et al. 1988) was not required for the formation of $\mathrm{Cl}$ and C2 complexes (Greaves and O'Hare 1990; Kristie et al. 1989; Werstuck and Capone 1989), only the interactive domain (amino acid $1-412$ ) was produced as an inframe fusion product with the Staphylococcus aureus protein A (PA- $\alpha \mathrm{TIF})$. The domain encoding the Oct-1 POU domain (amino acid 270-441) was similarly produced as a protein A fusion product (PA-POU). Bacteria containing the appropriate plasmids were induced to express the fusion proteins, lysates were prepared, and the proteins were purified by chromotography on IgG-Sepharose. Analysis by SDS-PAGE revealed the expected 74-kD (PA- $\alpha \mathrm{TIF})$ and $48-\mathrm{kD}$ (PA-POU) purified fusion proteins (data not shown).

As anticipated, PA-POU readily bound the $\mathrm{HSV}_{\alpha} 0$ $\alpha /$ IE element DNA probe, forming the PA-POU/DNA complex (Fig. 1A). Addition of either the bacterially produced PA- $\alpha$ TIF or an $\mathrm{S} 100$ extract $(\mathrm{Cl}$ factor) prepared from SF9 insect cells did not affect the PA-POU/DNA complex or result in the formation of additional DNAprotein complexes. However, addition of both PA- $\alpha$ TIF and the $\mathrm{Cl}$ factor extract to the reaction containing PAPOU generated the first $\alpha$ TIF-dependent complex $(\mathrm{C} 1)$.

Addition of a HeLa cell nuclear extract, which had been depleted of Oct-1, to a reaction containing the $\mathrm{Cl}$ complex generated the slower mobility $\mathrm{C} 2$ complex. This suggests that the $\mathrm{C} 2$ complex contains a fourth component derived from the HeLa cell extract. Formation of both the $\mathrm{Cl}$ and $\mathrm{C} 2$ complexes could, alternatively, be generated by the addition of PA-POU and PA- $\alpha$ TIF to the the octamer-depleted HeLa cell nuclear extract (data not shown). Thus, the $\mathrm{Cl}$ factor is present in both SF9 insect cell and HeLa cell extracts, whereas the $\mathrm{C} 2$ factor is only present in the HeLa cell nuclear extracts.

\section{Partial purification of the C1 factor}

The $\mathrm{C} 1$ factor was partially purified from $\mathrm{S} 100$ extracts of SF9 cells, as these extracts do not contain octamerbinding and $\mathrm{C} 2$ factor activities. Extracts were chromatographed on a DEAE-Sepharose column, and the bound proteins were eluted by successive step washes of 200,350 , and $500 \mathrm{mM} \mathrm{KCl}$. Column fractions were assayed in the presence of PA-POU and PA- $\alpha$ TIF for the ability to support the formation of the $\mathrm{Cl}$ complex (Fig. 1B). The $\mathrm{Cl}$ factor activity eluted from the DEAE column at $350 \mathrm{~mm} \mathrm{KCl}$ (fractions 28-33, lanes 6-11), resulting in a 10 -fold purification $(\mathrm{DE}-\mathrm{Cl}$ a). As evident with the original SF9 S100 extract, formation of the $\mathrm{Cl}$ complex was dependent on the addition of PA-POU, 

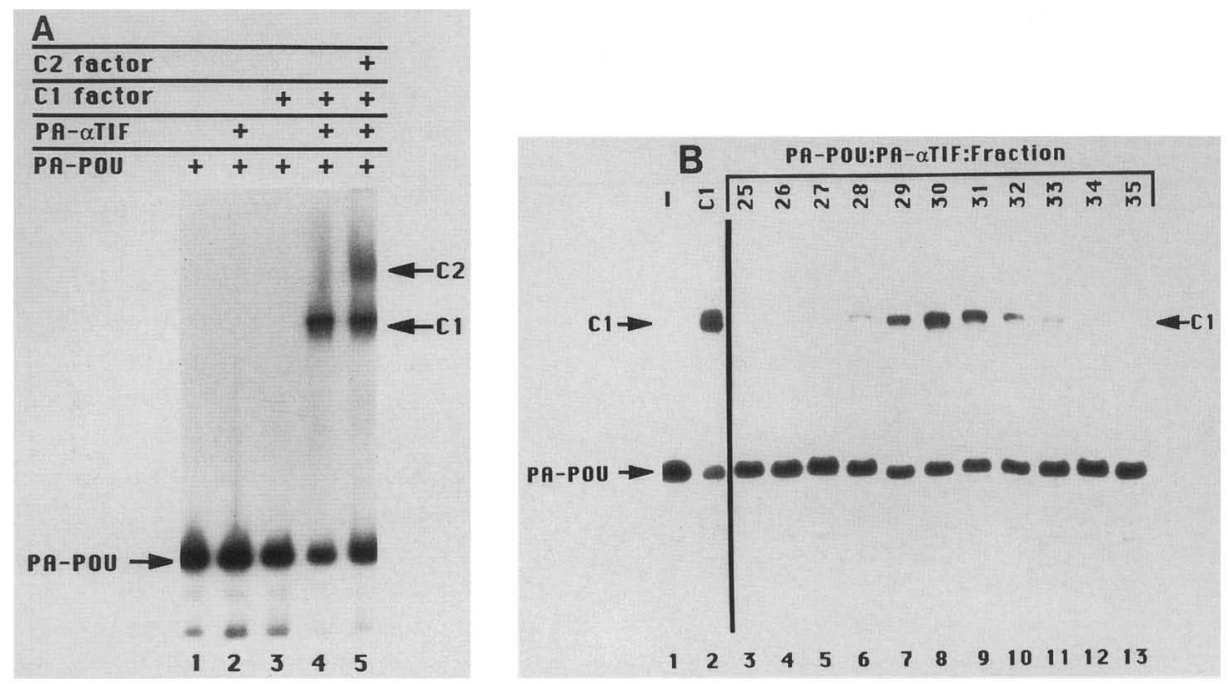

Figure 1. Assembly of PA-POU and PA- $\alpha$ TIF into multiprotein complexes on the $\alpha /$ IE element: requirement for $\mathrm{C} 1$ and $\mathrm{C} 2 \mathrm{factors}$. Protein-DNA-binding reactions were done as described in Materials and methods with $1000 \mathrm{ng}$ poly[d(I-C)]/poly[d(I-C)]. The probe DNA, HSV $\alpha 0$, was derived from pRB608 and contains the $\alpha /$ IE element from -168 to -142 of the $\alpha 0$ promoter (Mackem and Roizman 1980|. The positions of the PA-POU/DNA, C1, and C2 complexes are indicated with arrows. $(A)$ The proteins included in each binding reaction are indicated at the top of the autoradiogram $1+1$ and are as follows: $25 \mathrm{ng}$ PA-POU; $50 \mathrm{ng}$ PA- $\alpha$ TIF; C1 factor, $5 \mu \mathrm{g}$ SF9 cell S100 extract; C2 factor, $5 \mu \mathrm{g}$ of nuclear extract from HeLa cells, which was depleted of Oct-1 by affinity chromotography. $(B)$ Chromatographic fractionation of the CI factor on DEAE-Sepharose. Protein-DNA-binding reactions contained 25 ng PA-POU, $50 \mathrm{ng}$ PA $-\alpha \mathrm{TIF}$, and $1 \mu \mathrm{l}$ of the column load $(\mathrm{Cl})$ or $2 \mu \mathrm{l}$ of the indicated fraction from the DEAE-Sepharose chromatography. $1-$, lane 1) A reaction in the absence of added $\mathrm{Cl}$ extract.

PA- $\alpha$ TIF, and the DEAE fractions. This activity was further purified sixfold by reapplication of the $\mathrm{DE}-\mathrm{Cl}$ a activity to a higher resolution DEAE-Sepharose column and elution with a linear gradient of $200-400 \mathrm{mM} \mathrm{KCl}$. The $\mathrm{Cl}$ activity eluted at $270-290 \mathrm{~mm} \mathrm{KCl}(\mathrm{DE}-\mathrm{Clb})$. $\mathrm{DE}-\mathrm{Clb}$ activity was subsequently applied to a heparin-agarose column and eluted with a linear gradient of $50-150 \mathrm{mM} \mathrm{KCl}$, followed by successive steps to 250 and $350 \mathrm{~mm} \mathrm{KCl}$. With these conditions, the $\mathrm{DE}-\mathrm{Clb}$ activity was resolved into two distinct $\mathrm{Cl}$ species $\mathrm{C}$ Cl and $\mathrm{Cl}^{\prime}$ ), which elute at $125-200$ and $250 \mathrm{mM} \mathrm{KCl}$, respectively. Both species generated a Cl-type complex that was dependent on the addition of $\alpha$ TIF and PAPOU. However, the $\mathrm{Cl}$ complex generated with the activity eluting at $125 \mathrm{~mm} \mathrm{KCl}$ migrated slightly faster than the respective $\mathrm{Cl}$ complex generated with the activity eluting at $250 \mathrm{~mm} \mathrm{KCl}$. Treatment of the $\mathrm{Cl} \mathrm{ac}$ tivity eluting at $250 \mathrm{mM} \mathrm{KCl}$ with phosphatase resulted in the formation of a $\mathrm{Cl}$ complex with the faster mobility, suggesting that the two forms of $\mathrm{Cl}$ differ in their degree of phosphorylation (data not shown). The heparin-agarose chromatography resulted in an additional sixfold purification of the predominant $\mathrm{Cl}$ activity $(\mathrm{H}-\mathrm{Cl})$.

Neither PA $-\alpha$ TIF nor the partially purified $\mathrm{Cl}$ factor had sequence-specific DNA-binding activity when assayed under the standard conditions. However, the $\mathrm{Cl}$ complex protects the sequences $3^{\prime}$ to the octamer element in the $\mathrm{HSV} \alpha 0$ probe from metal ion cleavage (Kristie et al. 1989). It was therefore anticipated that the $\mathrm{Cl}$ factor would represent this second DNA-binding specificity. To address this, fractions containing the $\mathrm{Cl}$ activity $(\mathrm{H}-\mathrm{Cl})$ were chromatographed on ds DNA-cellulose and denatured DNA -cellulose columns. Surprisingly, the $\mathrm{H}-\mathrm{Cl}$ activity was recovered exclusively in the flowthrough fractions from these columns, suggesting that the $\mathrm{Cl}$ factor does not possess independent, high-affinity DNA-binding activity.

Interactions of aTIF, the Oct-1 POU domain, and the C1 factor in the absence of DNA

The $\mathrm{Cl}$ complex contains the Oct-1 protein, $\alpha \mathrm{TIF}$, and the $\mathrm{Cl}$ factor. To assess the interactions involved in this multiprotein complex, the $\mathrm{Cl}$ factor $(\mathrm{DE}-\mathrm{Clb})$ was chromatographed on a PA $-\alpha$ TIF or PA-POU protein-affinity column. Purified PA- $\alpha$ TIF or PA-POU was batch-adsorbed to IgG-Sepharose, resulting in affinity matrices containing $400 \mu \mathrm{g}$ of the appropriate fusion protein per milliliter of resin. $\mathrm{DE}-\mathrm{Cl}$ b activity was $\mathrm{ab}$ sorbed to each affinity matrix and the columns were successively washed with 50,150 , and $500 \mathrm{mM} \mathrm{KCl}$. All of the DE-Clb activity bound to the $\alpha$ TIF column and was eluted by $500 \mathrm{~mm} \mathrm{KCl}$ (Fig. 2, lanes 9-16). In contrast, $80 \%$ of the $\mathrm{Cl}$ activity did not bind the PA-POU affinity matrix and was found in the flowthrough fractions from this column. The remaining $20 \%$ was eluted from the PA-POU column in the $150 \mathrm{~mm} \mathrm{KCl}$ wash /data not shown). Thus, the $\mathrm{Cl}$ factor binds $\alpha \mathrm{TIF}$ with high affinity in the absence of the $\alpha /$ IE element and the Oct- 1 protein. Conversely, this component has limited or no apparent affinity for the Oct-1 POU domain protein under these conditions. Similarly, the $\mathrm{Cl}$ factor but not the $\mathrm{C} 2$ factor, present in HeLa cell nuclear extracts, also 


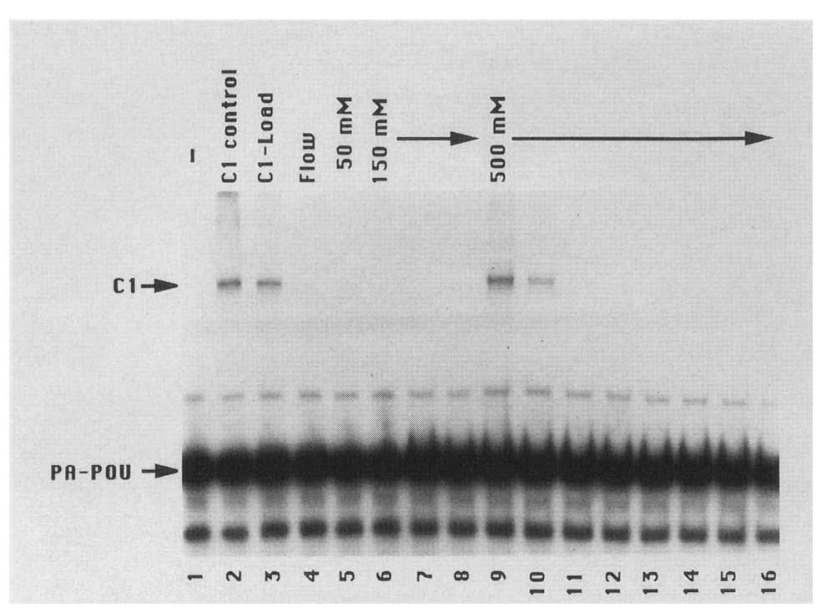

Figure 2. Affinity chromatography of the $\mathrm{Cl}$ factor on a PA$\alpha$ TIF affinity matrix. Protein-DNA-binding reactions contained $750 \mathrm{ng}$ poly[d(I-C)]/poly[d(I-C)] and $25 \mathrm{ng}$ PA-POU, 50 ng PA- $\alpha \mathrm{TIF}$, and the following protein fractions as indicated: (Lane 1) No additional protein extract; (lane 2) $2 \mu \mathrm{g}$ of SF9 cell S100 extract; (lane 3) $1.5 \mu$ l of the DE-Cla column load; (lane 4) $2 \mu \mathrm{l}$ of the column flowthrough fraction; (lanes 5-16) $2 \mu \mathrm{l}$ of the indicated $\mathrm{KCl}$ step fractions from the column. The positions of the PA-POU/DNA and Cl complexes are indicated with arrows.

bound the $\alpha$ TIF matrix with high affinity and specificity. This factor was eluted from the $\alpha$ TIF column by $650 \mathrm{~mm}$ $\mathrm{KCl}$, whereas control DNA-binding proteins were found exclusively in the flowthrough fractions /data not shown).

As the $\mathrm{Cl}$ factor did not exhibit high affinity for the POU domain fusion protein, $\alpha$ TIF (purified from recombinant baculovirus-infected SF9 cells) was chromatographed on the PA-POU and control PA affinity columns. Fractions from the columns were assayed by gel mobility shift for the formation of the $\mathrm{Cl}$ complex in the presence of PA-POU and the $\mathrm{Cl}$ factor. In both cases, all of the $\alpha$ TIF protein was found in the flowthrough and $150 \mathrm{mM} \mathrm{KCl}$ washes from these columns (data not shown). This suggests that any possible interactions between Oct- 1 and $\alpha$ TIF are not of high affinity in the absence of the $\alpha /$ IE element and the Cl factor.

\section{Purified aTIF specifically binds to the HSV a/IE element with low affinity}

Several attempts have been made to detect the direct binding of $\alpha \mathrm{TIF}$, purified from HSV virions, to the $\alpha / \mathrm{IE}$ element (Marsden et al. 1987; Preston et al. 1988). However, we took advantage of the high level of $\alpha$ TIF production in the baculovirus expression system to assay the DNA-binding potential of this protein. At high concentrations of purified $\alpha$ TIF, several novel DNA-protein complexes were detected in a gel mobility shift assay. One of these complexes had a mobility that was expected of an $\alpha$ TIF/DNA complex. Due to the high protein concentration required for the formation of this complex, it was possible that it represented the binding of a cofractionating protein in the $\alpha$ TIF protein fractions. Therefore, $\alpha$ TIF was further purified by preparative SDSPAGE. The $53-\mathrm{kD}$ doublet, representing the $\alpha$ TIF proteins was eluted from the gel, denatured in guanidine/ $\mathrm{HCl}$, and allowed to renature during dialysis. The gelpurified protein formed a novel doublet of complexes with the $\mathrm{HSV} \alpha 0$ probe (Fig. 3A, lane 1). This doublet of complexes was also formed, although less efficiently, with the wild-type probe (lane 4). This probe is several nucleotides shorter $\left(3^{\prime}\right.$ end $)$ than the $\mathrm{HSV} \alpha 0$ probe but maintains the highly conserved core TAATGARAT. However, a double point mutation in either the $5^{\prime}$ or $3^{\prime}$ region of the core sequence abolished the formation of the DNA-protein complexes (lanes 2 and 3). This sequence specificity is distinct from that of Oct-1, which is affected only by the $5^{\prime}$ double point mutation. It is,
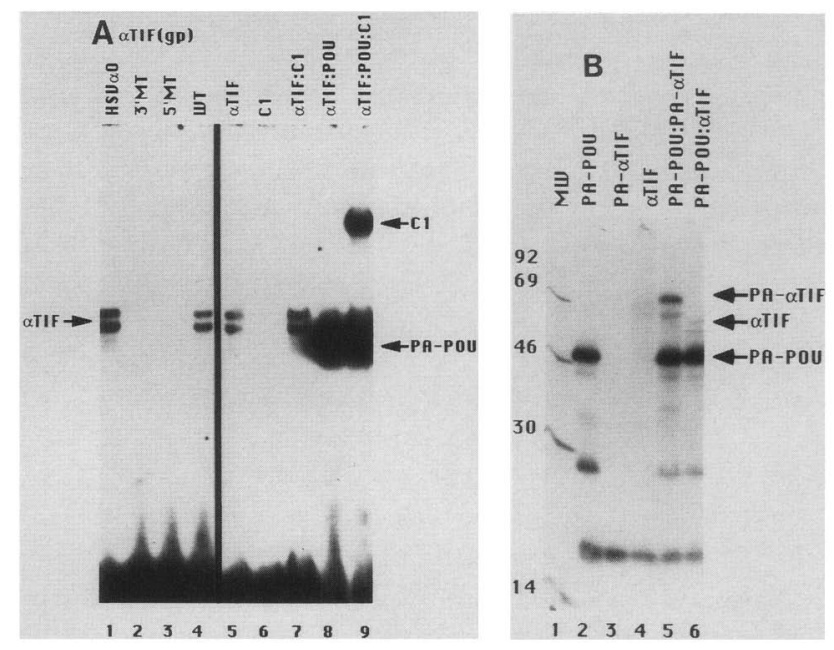

Figure 3. Independent binding of $\alpha$ TIF to the $\alpha /$ IE element and cooperative binding with the Oct-1 PA-POU domain protein. (A) Protein-DNA-binding reactions contained $30 \mathrm{ng}$ poly[d/I$\mathrm{C} \mid) /$ poly $[\mathrm{d}(\mathrm{I}-\mathrm{C})]$ and the following proteins where indicated: [ $\alpha$ TIF(gp)] $300 \mathrm{ng}$ baculovirus-expressed and SDS-PAGE-purified $\alpha$ TIF; (Cl) $2.5 \mu \mathrm{l} \mathrm{DE}-\mathrm{Cl}$ a fraction; (POU) $25 \mathrm{ng}$ PA-POU. Left $\mid$ Binding reactions contained the following DNA probes indicated at the top of the autoradiogram: (HSV $\alpha 0) 5^{\prime}$ CCGTGCATGCTAATGATATTCTTTGGGG-3'; (WT) wildtype 5'-CGTGCATGCTAATGATATTCTTG-3'; (5'MT) 5'CGTGCATGCGACTGATTCTTG-3'; (3'MT) 5'-CGTGCATGCTAATG TETTCTTG-3', where the point mutations are underlined. The positions of the $\alpha$ TIF/DNA, PA-POU/ DNA, and $\mathrm{Cl}$ complexes are indicated with arrows. Both panels represent segments taken from the same autoradiogram. $|B|$ Protein-DNA-binding and UV-cross-linking reactions were done as described in Materials and methods with $150 \mathrm{ng}$ poly $[\mathrm{d}(\mathrm{I}-\mathrm{C})] /$ poly $[\mathrm{d}(\mathrm{I}-\mathrm{C})]$ and the following SDS-PAGE-purified proteins where indicated: $30 \mathrm{ng}$ PA-POU, $100 \mathrm{ng} \mathrm{PA}-\alpha \mathrm{TIF}$, or $60 \mathrm{ng} \alpha \mathrm{TIF}$. Lane 1 contains ${ }^{14} \mathrm{C}$ protein molecular weight markers whose sizes (in $\mathrm{kD}$ ) are indicated at left. The positions of the PA- $\alpha$ TIF (74 kD), PA-POU (46 kD), and $\alpha$ TIF ( $53 \mathrm{kD}$ ) are indicated with arrows. The $27-\mathrm{kD}$ radioactive protein species is a degradation product of PA-POU. The radioactive band at 17 $\mathrm{kD}$ represents the digested DNA and is present in control reactions in the absence of protein. 
however, consistent with the formation of the $\mathrm{Cl}$ complex that is inhibited by either the $5^{\prime}$ or $3^{\prime}$ double point mutations. The gel-purified $\alpha$ TIF protein did not form an additional, stabile complex in the presence of either the $\mathrm{Cl}$ factor (DE-Clb) or PA-POU but was functional to form the $\mathrm{Cl}$ complex in the presence of both proteins (Fig. 3A, right).

Equivalent assays using gel-purified PA $-\alpha$ TIF also exhibited a novel DNA-protein complex with the anticipated mobility of a PA- $\alpha$ TIF/DNA complex $/ 74-\mathrm{kD}$ protein|. The DNA-binding specificity of this protein was identical to that of the baculovirus-expressed $\alpha$ TIF with respect to the wild-type, 5'MT and 3'MT probes. However, the binding efficiency of the renatured PA- $\alpha$ TIF was less than that of the renatured $\alpha$ TIF from the SF9 cells (data not shown).

The DNA-binding activity of $\alpha$ TIF was inhibited by the inclusion of $\mathrm{MgCl}_{2}(0.1-2 \mathrm{~mm})$ in the binding reaction but was stimulated by a cycle of denaturation and renaturation of the protein. Gel mobility assays, in which either the protein in the $\alpha$ TIF column fractions or the gel-purified protein was first denatured with guanidine $/ \mathrm{HCl}$ and partially renatured by dilution, exhibited a 15-fold stimulation of DNA-binding activity over equivalent amounts of untreated protein (data not shown). One possible explanation for this phenomenon is that $\alpha$ TIF, consistent with its form and function in the tegument structure of the HSV virion, readily aggregates and precipitates from solution at high protein concentrations. The cycle of denaturation and renaturation at dilute concentrations may increase the percent of soluble monomeric protein. Alternatively, the protein may require a conformational change to expose its DNA. binding domain. Regardless of these possibilities, $\alpha$ TIF represents a second DNA-binding specificity in the assembly of the $\mathrm{C} 1$ and $\mathrm{C} 2$ complexes.

The DNA binding activity of aTIF is stimulated by the binding of the Oct-1 POU domain in the absence of the C1 factor

No apparent interactions could be detected between PA-POU and $\alpha$ TIF, either in the absence of DNA or in a gel mobility shift assay (see above). However, UV-crosslinking reactions revealed a potential cooperative DNAbinding interaction between these proteins. $\mathrm{HSV} \alpha 0$ DNA was uniformly labeled by the incorporation of $\left.{ }^{32} \mathrm{P}\right] \mathrm{dNTP}$ and was incubated with proteins purified and renatured with SDS-PAGE. The binding reactions were UV-irradiated, digested with nucleases, and resolved on an SDS-denaturing gel. Reactions containing high concentrations of PA $-\alpha$ TIF or $\alpha$ TIF revealed unique radioactive protein products of 74 and $53 \mathrm{kD}$, respectively /data not shown). This supports the conclusion that these two forms of the $\alpha$ TIF protein have inherent, independent, DNA-binding potential. More significantly, as illustrated in Figure 3B, the binding PA-POU to the octamer element in the $\mathrm{HSV} \alpha 0$ probe stimulated the efficiency of UV cross-linking of the $\alpha$ TIF proteins significantly. Reactions containing gel-purified PA-POU exhibited the anticipated $48-\mathrm{kD}$ radioactive product (Fig. 3B, lane 2 ). In this set of experiments, no significant UV crosslinking of $\alpha$ TIF-related proteins was detected in reactions containing reduced concentrations of PA $-\alpha$ TIF or $\alpha$ TIF alone (lanes 3 and 4). However, addition of PAPOU to identical reactions containing either PA- $\alpha$ TIF (lane 5) or $\alpha$ TIF (lane 6), stimulated the efficiency of UV cross-linking by 15 -fold of the respective 74 - or $53-\mathrm{kD}$ proteins. No stimulation of the cross-linking of $\alpha \mathrm{TIF}$ was recorded in control reactions containing the $\alpha \mathrm{TIF}$ proteins and PA. In addition, in cross-linking reactions with the wild-type, $5^{\prime} \mathrm{MT}$, and $3^{\prime} \mathrm{MT}$ probes, PA-POU did not bind to the $5^{\prime}$ MT probe DNA and did not stimulate the efficiency of cross-linking of $\alpha$ TIF. In contrast, the cross-linking of $\alpha$ TIF was stimulated by the binding of PA-POU to the wild-type and 3'MT probes. As $\alpha$ TIF does not bind the $3^{\prime} \mathrm{MT}$ probe independently, it is likely that the stimulation observed with this probe represents the importance of the cooperative interaction between PA-POU and $\alpha$ TIF (data not shown). Thus, the cooperative DNA binding of the $\alpha$ TIF/PA-POU proteins, as indicated by the increase in the efficiency of UV crosslinking, required the binding of PA-POU to the octamer element. To demonstrate definitively that the novel 74 and $53-\mathrm{kD}$ species represented PA- $\alpha$ TIF and $\alpha \mathrm{TIF}$, respectively, the SDS-PAGE-resolved reaction products were blotted with an anti- $\alpha$ TIF sera. This sera reacted specifically with the anticipated radioactive bands (data not shownl.

Similar UV cross-linking reactions with fractions containing the $\mathrm{Cl}$ factor $(\mathrm{H}-\mathrm{Cl})$ exhibited minor DNAbinding species of 45 and $55 \mathrm{kD}$. However, no stimulation of the DNA-binding activity of $\alpha$ TIF was observed in reactions containing this protein and the $\mathrm{H}-\mathrm{Cl}$ fractions. Additionally, no alteration in the cross-linking pattern was seen in reactions containing $\mathrm{PA}-\mathrm{POU} / \mathrm{Cl}$ or $\mathrm{PA}-\mathrm{POU} / \mathrm{PA}-\alpha \mathrm{TIF} / \mathrm{Cl}$ as compared to equivalent reactions in the absence of the $\mathrm{Cl}$ activity (data not shown).

The homeo box of Oct-1 binds the HSVaO site cooperatively and interacts with aTIF/C1

The POU domain of Oct-1 contains all of the determinants required for the high-affinity binding to the octamer element and for the specific interaction with $\alpha \mathrm{TIF} / \mathrm{Cl}$. This domain consists of the highly conserved POU-specific box and the POU homeo box. To investigate the roles of these subdomains in the assembly of the $\mathrm{Cl}$ complex, PA fusion proteins were produced consisting of either the POU-specific box (PA-Poubox, amino acids $270-368$ ) or the POU homeo box (PAhomeo box, amino acids $368-441$ ). The purified proteins were compared to the intact POU domain (PA-POU) for the ability to bind to the HSV $\alpha 0$ DNA probe and to interact with the $\alpha \mathrm{TIF} / \mathrm{Cl}$ proteins. Titration of PA-POU in DNA-binding reactions determined that this protein bound the octamer homolog in the HSV $\alpha 0$ probe with a $\mathrm{kD}$ of $\sim 3.5 \times 10^{-10} \mathrm{M}$. This affinity was not significantly different than that exhibited by the protein in re- 
actions containing a consensus octamer element probe $\left(\mathrm{kD}=\sim 2.2 \times 10^{-10} \mathrm{M}\right)$. Similarly, in reactions containing a constant concentration of $\mathrm{PA}-\alpha \mathrm{TIF}$ and $\mathrm{Cl}$ factor, formation of the multiprotein PA-POU/ $\alpha$ TIF/Cl complex was only twofold more efficient than formation of the PA-POU/DNA complex. Therefore, the primary determinant in the affinity of the multiprotein $\mathrm{Cl}$ complex for the $\alpha / \mathrm{IE}$ site is the recognition of this element by the Oct-1 POU domain.

The POU-specific box subdomain (PA-Poubox) did not exhibit significant binding to the consensus octamer or the $\mathrm{HSV}_{\alpha} 0$ probes and did not support the formation of a $\mathrm{Cl}$ complex in the presence of $\alpha \mathrm{TIF}$ and $\mathrm{Cl}$ factor. In contrast, the homeo box subdomain (PA-homeo box) bound the consensus octamer element but had a significantly lower affinity than PA-POU $\left(\mathrm{kD}=\sim 2.3 \times 10^{-5}\right.$ M). Additionally, as shown in Figure 4 (lanes 1 and 2), PA-homeo box formed a protein/HSV $\alpha 0$ DNA complex with an electrophoretic mobility expected of a PAhomeo box homodimer/DNA complex [cf. the migration of PA-POU/DNA (lane 5) with PA-homeo box/DNA (lanes 1 and 2)]. The mobility of this complex was slower than that of the PA-homeo box/consensus octamer element complex and equivalent to that of a dimeric complex formed by the binding of PA-homeo box to a dimeric consensus octamer element. Additional results also support the dimeric nature of the PA-homeo box/ HSV $\alpha 0$ DNA complex. As shown below, the PA-homeo

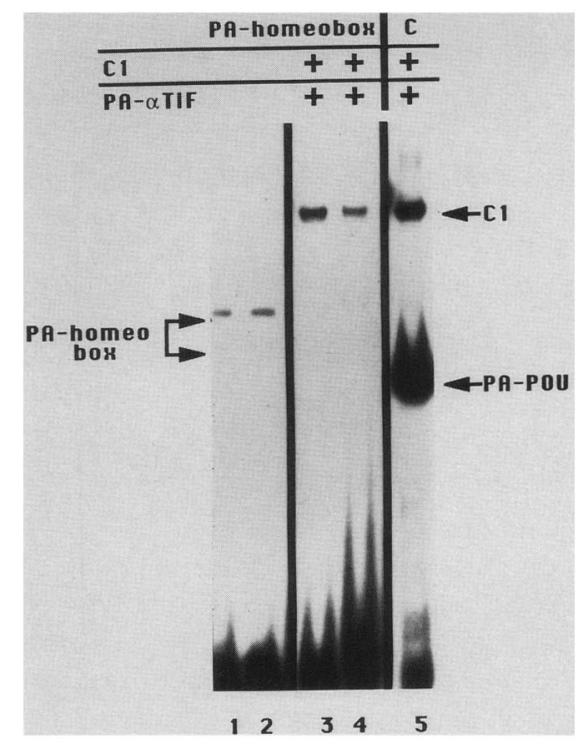

Figure 4. The Oct-1 homeo box (PA-homeo box binds the $\alpha /$ IE element cooperatively and forms an $\alpha$ TIF-dependent $\mathrm{Cl}$ complex. Protein-DNA-binding reactions contained $200 \mathrm{ng}$ poly[d(I-C)/poly[d(I-C)] and the following proteins: (Lanes 1 and 3) $350 \mathrm{ng}$ PA-homeo box; (lanes 2 and 4) $700 \mathrm{ng}$ PA-homeo box; (lane 5) $25 \mathrm{ng}$ PA-POU. Lanes 3-5 contained, in addition to the Oct-1 fusion protein, $100 \mathrm{ng} \mathrm{PA}-\alpha \mathrm{TIF}$ and $2 \mu \mathrm{l}$ of the $\mathrm{DE}-\mathrm{Cl}$ fraction, as indicated at $\operatorname{top}(+1$. Each panel is derived from the same gel autoradiogram. The positions of the PAhomeo box/DNA, PA-POU/DNA, and Cl complexes are indicated with arrows. box protected a dimeric binding site in the $\mathrm{HSV} \alpha 0$ element from $\mathrm{Cu} /$ phenanthroline cleavage. Titration of PA-homeo box did not exhibit any indication of a monomer PA-homeo box/DNA complex, suggesting that the protein bound the $\mathrm{HSV} \alpha 0$ probe only via a highly cooperative interaction. Furthermore, binding of the PA-homeo box dimer to the $\mathrm{HSV} \alpha 0$ probe required 10 -fold less protein than the equivalent monomeric binding to the consensus octamer element. In contrast, titration of the intact POU domain protein (PA-POU) to high concentrations showed no evidence of cooperative, dimeric binding to this probe (data not shown), although it is clear that the POU domain of the Oct proteins can exhibit cooperative binding to appropriately spaced and oriented octamer elements (LeBowitz et al. 1989). The binding of PA-homeo box to the HSV $\alpha 0$ probe suggests that this 60-amino-acid DNA-binding domain has the potential for cooperative interactions.

As $\mathrm{PA}$-homeo box bound the $\mathrm{HSV} \alpha \mathrm{O}$ probe, it was tested directly for its ability to form a $\mathrm{Cl}$ complex in the presence of PA- $\alpha$ TIF and the $\mathrm{Cl}$ factor. As shown in Figure 4 (lanes 3 and 4 ), this protein was fully capable of forming the $\mathrm{C} 1$ complex. In parallel binding reactions containing equivalent concentrations of $\alpha \mathrm{TIF} / \mathrm{Cl}$ factor, however, the formation of equivalent amounts of the Cl-type complexes occurred at a $10^{2}$ lower concentration of PA-POU than PA-homeo box. This lower efficiency of formation of the $\mathrm{Cl}$ complex is probably accounted for by the $10^{4}$-fold difference in DNA-binding affinity between the PA-homeo box and PA-POU proteins. Thus, the interactions between either the PAhomeo box or the PA-POU and the PA- $-\alpha$ TIF/C1 factor may be of comparable affinity.

Because the Oct-1 POU-specific box (PA-Poubox) did not bind the HSV $\alpha 0$ DNA under these conditions, it could not be directly assessed for interactions with the $\alpha \mathrm{TIF}$ and $\mathrm{Cl}$ factors. Therefore, this protein was used as a competitor in a $\mathrm{Cl}$ complex formation assay. Increasing molar amounts of PA-Poubox, PA-homeo box, or PA proteins were added to a $\mathrm{Cl}$ formation reaction consisting of $\mathrm{PA}-\mathrm{POU} / \mathrm{PA}-\alpha \mathrm{TIF} / \mathrm{Cl}$ factor. Inclusion of either the control PA or the PA-Poubox proteins in these reactions did not affect the formation of the PA-POU/DNA and C1 complexes at a 100-fold molar excess over the concentration of the PA-POU protein. However, inclusion of PA-homeo box specifically competed for a component (PA- $\alpha$ TIF or the $\mathrm{Cl}$ factor) of the $\mathrm{C} 1$ complex under conditions where the DNA binding of PA-POU was unaffected (data not shown).

Consistent with its interactions with a component of the $\mathrm{Cl}$ complex and its ability to support the formation of the $\mathrm{Cl}$ complex, PA-homeo box bound the $\mathrm{HSV}_{\alpha} 0$ probe and specifically stimulated the binding of either PA $-\alpha$ TIF or $\alpha$ TIF in the UV-cross-linking assays/data not shown|. As anticipated, PA-Poubox did not exhibit either significant DNA binding or cooperative interactions with the $\alpha$ TIF proteins in equivalent assays. Thus, the homeo box of the Oct-1 protein appears to contain most, if not all, of the determinants required for the interaction with $\alpha \mathrm{TIF} / \mathrm{C} 1$ factor. 
Protection of the HSVaO DNA from orthophenanthroline/Cu cleavage by the PA-homeo box dimer, $P A-P O U$, and PA-homeo box-C1 complex

The HeLa cell Oct-1 protein protects the octamer homolog in the HSV $\alpha 0$ probe from cleavage by orthophenanthroline/Cu (Kristie et al. 1989). Furthermore, the Oct-1/ $\alpha \mathrm{TIF} / \mathrm{Cl}$ complex extends this protection to encompass the entire HSV $\alpha /$ IE element. As shown in Figure 5, A and B, PA-POU and the PA-POU-Cl complex afforded a protection equivalent to that of the intact Oct-1 and Oct-1-Cl complex, respectively. In contrast, the PA-homeo box-C1 complex protected only a portion of the octamer homolog but protected the remainder of the $\alpha /$ IE site in an identical fashion to that of the PA-POU-Cl complex. Of significant note is the lack of protection of the first several nucleotides of the octamer homolog, which was protected by the intact POU domain protein (Fig. 5A, cf. all lanes and Fig. 5B, $5^{\prime}$-ATGC-3' (top strand) and 5'-TGC-3' (bottom strand)]. Assuming that the homeo box subdomain occupies the same position in the PA-homeo box-Cl complex and the PA-POU-Cl complex, this lack of protection by PA-homeo box indicates that the POU-specific box subdomain contributes directly to the recognition of the octamer element. The octamer sequence therefore appears to be a bipartite element that is recognized by the two subregions of the POU domain.

As illustrated in Figure 5, A (left) and B, the apparent PA-homeo box homodimer also did not protect the 5 ' part of the octamer homolog but did protect sequences $3^{\prime}$ to the octamer element in the $\alpha / \mathrm{IE}$ site. This additional protection probably reflects the binding of the second PA-homeo box protein.

\section{Discussion}

A wide variety of regulatory processes are dependent on an octamer DNA element. Even the existence of discrete octamer-binding proteins such as Oct-1 and Oct-2 cannot solely account for the role of this sequence in the distinct regulation of different cellular genes. Differen-

Figure 5. Protection from orthophenanthroline/Cu cleavage of the HSV $\alpha 0$ DNA sequences by PA-homeo box, PA-POU, and the $\mathrm{PA}$-homeo box-Cl complex. $\{A \mid$ Protein-DNA-binding and cleavage reactions of electrophoretically resolved proteinDNA complexes were done as described in Materials and methods and the legend to Fig. 4. Purified DNA cleavage products were resolved in a $10 \%$ sequencing gel. (Free) The cleavage products of the unbound DNA. (GA) A guanine plus adenine sequencing reaction ladder (Maxam and Gilbert 1980). The nucleotide sequence of the noncoding coding strand of the HSV $\alpha 0$ DNA probe is $\left(5^{\prime}\right.$ to $3^{\prime}$, top to bottom) at left and right. (B) The bars schematically delineate the boundaries of the protection from orthophenanthroline/Cu for the noncoding $\mid$ top $\mid$ and coding (bottom) strands of the HSV $\alpha 0$ probe. (I Nucleotides that are partially protected. The consensus octamer (Falkner and Zachau 1984) sequence is aligned above. (POU and homeo box/ PA-POU and PA-homeo box, respectively. The protection limits of the POU-Cl complex were published previously (Kristie et al. 1989). tial regulation, however, can be explained by the interaction of Oct-1 and Oct-2 with other proteins to form complexes resulting from the combined specificities of multiple factors. These hypothetical regulatory assemblies are modeled by the interaction of the HSV transactivator, $\alpha \mathrm{TIF}$, with the Oct-1, $\mathrm{Cl}$, and $\mathrm{C} 2$ proteins.

\section{Interactions and specificities in the assembly of the} aTIF-dependent complexes

The assembly of complexes on the $\alpha /$ IE element is initiated by the binding of Oct-1 to the octamer homolog
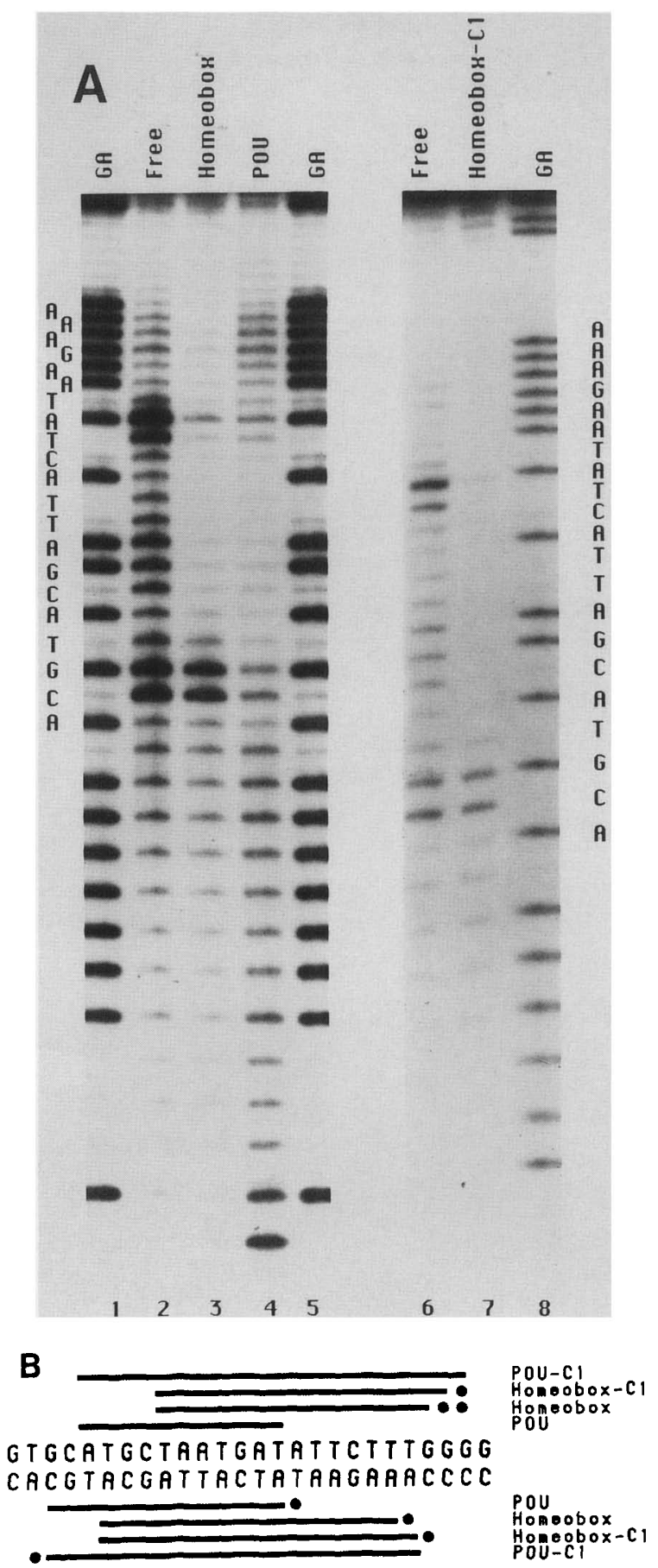

POU-Cl Honeobox POU Homeobox-C 


\section{A}
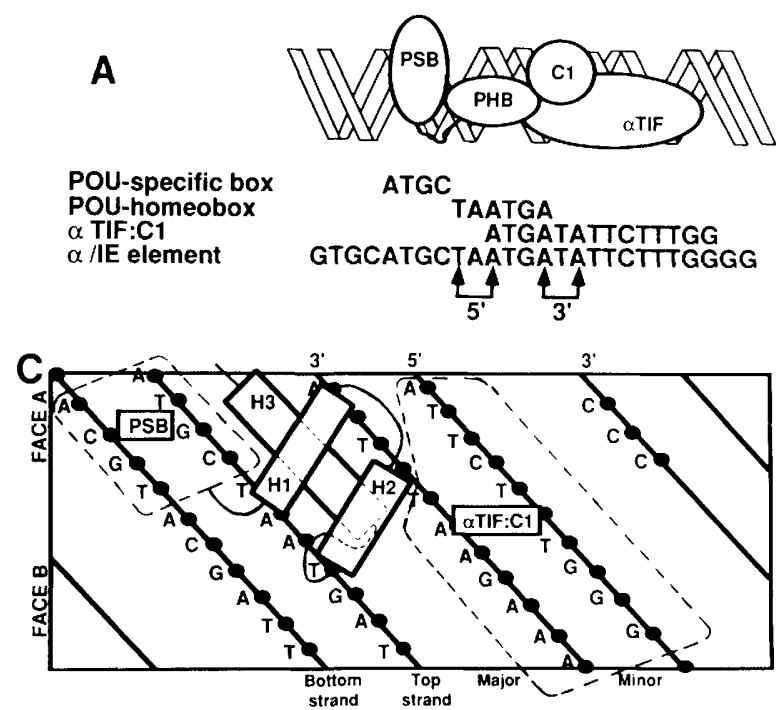

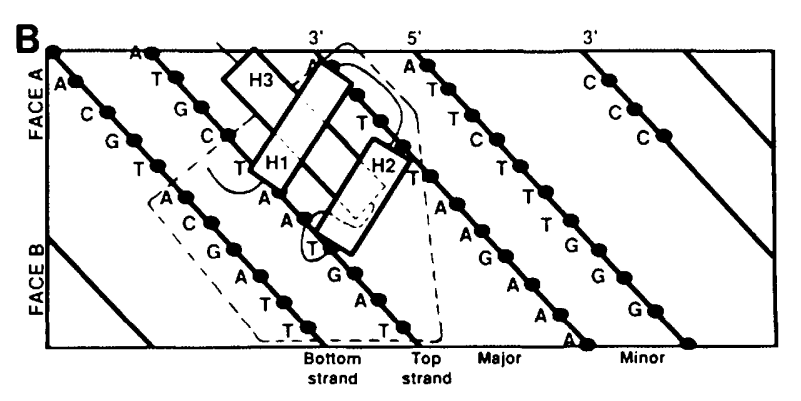

Figure 6. Interactions and sequence specificities involved in the assembly of the multiprotein $\mathrm{Cl}$ complex. $(A) \mathrm{A}$ schematic representation of the proteins that assemble on the $\alpha / \mathrm{IE}$ element. (PSB and PHB) The Oct-1 POU-specific box and POU homeo box, respectively. $\alpha$ TIF is positioned so as to make contact with the POU-homeo box and the HSV core sequence of the $\alpha / \mathrm{IE}$ element. The $\mathrm{Cl}$ factor is arbitrarily represented as a modulator of the $\alpha$ TIF activity. The DNA specificity of each of these components is shown below the diagram for the noncoding strand $\left(5^{\prime}\right.$ to $\left.3^{\prime}\right)$. The $3^{\prime}$ boundary of the binding site for the POU homeo box monomer was deduced from the $3^{\prime}$ boundary of the sequences protected by the intact POU domain. The sequences recognized by the POU-specific box are those nucleotides that are protected in the Cl-type complexes by the intact POU domain, but not by the POU homeo box. The DNA-binding specificity of the $\alpha \mathrm{TIF} / \mathrm{Cl}$ factor is based on the sequences protected by the $\mathrm{Cl}$ complex and the positions of the point mutations that interfere with the binding of $\alpha$ TIF. The positions of the double point mutants in the $\alpha /$ IE element $\left(5^{\prime}\right.$ and $\left.3^{\prime}\right)$ are shown and are described in the text and in the legend to Fig. 3. (B) The $\alpha /$ IE element is illustrated as a planar representation of the cylindrical projection of the DNA surface (Siebenlist et al. 1980; 10.5 bp per turn). The nucleotide sequence of the noncoding (top) and coding (bottom) DNA strand is written alongside the phosphate backbone ( $)$. The major and minor grooves of the DNA helix are indicated. (Faces A and B) The front and back faces of the helix, respectively. ( $\mathrm{Hl}-\mathrm{H} 3$ ) The three helices of the Oct-1 POU homeo box are arranged according to Qian et al. (1989) and oriented as described in the Discussion. The nucleotides protected from $\mathrm{Cu} /$ phenanthroline cleavage are enclosed by a dashed line. $|C|$ The $\alpha /$ IE element and the Oct-1 homeo box are represented as in $B$ with the deduced $\mathrm{Cu} /$ phenanthroline cleavage protections of the Oct-1 POU-specific box (PSB) and $\alpha$ TIF/Cl factor enclosed by the indicated dashed lines.

(Fig. 6A). This provides the basis for the subsequent binding of $\alpha \mathrm{TIF} / \mathrm{Cl}$ factor $(\mathrm{Cl}$ complex), followed by the association of the HeLa cell nuclear C2 factor (C2 complex; Kristie et al. 1989). A second sequence specificity is contributed by $\alpha$ TIF whose DNA binding is abolished by point mutations in the highly conserved TAATGArAT core of the $\alpha /$ IE element. The independent DNA-binding affinity of this protein is low and would, in vivo, undoubtedly require a cooperative interaction with Oct-1. Although $\alpha$ TIF interacts directly with the Oct-1 POU domain, no interaction was detected in the absence of the $\alpha /$ IE element, suggesting that this interaction is of low affinity. Thus, $\alpha$ TIF clearly represents a second DNA-binding specificity that is involved in the selection and activation of an $\alpha$-gene enhancer site.

The $\mathrm{Cl}$ factor, present in both SF9 insect cell extracts and HeLa cell nuclear extracts, represents a third determinant. Direct evidence for the presence of the $\mathrm{Cl}$ factor in the $\mathrm{Cl}$ complex derives from the chromatographic resolution of two modified forms of the $\mathrm{Cl}$ factor. These forms differ in their state of phosphorylation and generate $\mathrm{Cl}$ complexes of distinct mobilities. The association of the $\mathrm{Cl}$ factor with $\alpha \mathrm{TIF}$, in the absence of the $\alpha / \mathrm{IE}$ element, suggests that an $\alpha \mathrm{TIF} / \mathrm{Cl}$ factor complex may be the configuration with the highest affinity for DNA binding or interactions with Oct- 1 . The $\mathrm{Cl}$ factor may either induce a conformational change in $\alpha$ TIF, interact with both $\alpha$ TIF and Oct-1, or directly contribute to the recognition of the $\alpha / \mathrm{IE}$ site core sequences. As a cycle of denaturation-partial renaturation of $\alpha$ TIF increased its DNA-binding efficiency, a conformational alteration may be required for significant DNA recognition by this protein. The $\mathrm{Cl}$ factor may function by inducing such a conformational change. Alternatively, although the partially purified $\mathrm{Cl}$ factor does not possess detectable DNA-binding activity, this protein may be partially responsible for some sequence-specific binding in the $\mathrm{Cl}$ complex. In spite of this uncertainty with regard to its function, it is clear that the $\mathrm{Cl}$ factor is a chromatographically distinct component that interacts directly with $\alpha$ TIF in the absence of DNA and is required to form a stabile $\mathrm{Cl}$ complex.

In the biology of an HSV infection, the association of $\alpha \mathrm{TIF}$ and the $\mathrm{Cl}$ factor is probably critical for the initiation of infection. Productive infection of cells by HSV can be blocked by the expression of a mutant $\alpha$ TIF that lacks the trans-activation domain (Freidman et al. 1988; Triezenberg et al. 1988). It is possible that this inhibition resulted from the sequestering of the $\mathrm{Cl}$ factor by the mutant protein or by the formation of nonproductive C1-type complexes on the $\alpha /$ IE elements.

The fourth factor, C2, is present in nuclear extracts of HeLa cells and is required to assemble the larger C2 complex. This factor did not alter the metal ion cleavage protection of the $\alpha / \mathrm{IE}$ site by the $\mathrm{Cl}$ complex, nor was it retained on an $\alpha$ TIF protein matrix (data not shown). 
Therefore, the association of the $\mathrm{C} 2$ factor is mediated primarily by protein-protein interactions with Oct-1, the $\mathrm{Cl}$ factor, or a combination of the $\mathrm{Cl}$ complex components. The assembly of the $\mathrm{C} 1$ and $\mathrm{C} 2$ complexes thus depends on the interaction of multiple components that contribute both DNA-protein and protein-protein specificities to the selection and activation of particular octamer sites.

The role of the Oct-1 homeo box in the interaction with $a T I F / C 1$

Oct-1 and Oct- 2 are members of the POU family, which includes a large number of tissue-specific transcription factors (Herr et al. 1988; Thali et al. 1988; He et al. 1989; Johnson and Hirsch 1990). The conserved POU domain of these proteins is subdivided into the POU-specific box and the POU homeo box, which contains the helixturn-helix motif characteristic of the DNA-binding domains of the homeo box family (Laughon and Scott 1984; McGinnis et al. 1984; Clerc et al. 1988; Jordan and Pabo 1988; Ko et al. 1988; Otting et al. 1988; Sturm et al. 1988; Qian et al. 1989; Scott et al. 19891.

The fusion protein, containing only the POU-homeo box, bound the consensus octamer and the $\alpha /$ IE elements specifically but with a significantly lower affinity than the intact POU domain. In contrast to its binding to the consensus octamer, PA-homeo box bound the $\alpha /$ IE element as a homodimer (PA-homeo box/PAhomeo box/DNA). A monomeric PA-homeo box/DNA complex was not detected, indicating that the homeo box bound the $\alpha /$ IE element in a cooperative manner. This cooperative binding of PA-homeo box is probably due to the inverted repeat (TAATGAT/ATTCTTT) in the $\alpha /$ IE element that is related to the consensus homeo box element (TCAATTAAAT; Desplan et al. 1988; Hoey and Levine 1988; Muller et al. 1988a). Nonetheless, this suggests that the Oct-1 homeo box is capable of cooperative DNA-binding interactions.

Surprisingly, the Oct-1 homeo box protein (PAhomeo box / readily interacted with $\alpha \mathrm{TIF} / \mathrm{Cl}$ to form a C1-type complex. In contrast, the POU-specific box protein (PA-Poubox) did not form a $\mathrm{Cl}$ complex with $\alpha \mathrm{TIF} / \mathrm{Cl}$ factor, nor was it able to compete for these proteins. Additionally, UV-cross-linking reactions with PA-homeo box and $\alpha$ TIF exhibited a specific interaction between these two proteins in a manner equivalent to that of the intact Oct-1 POU domain and $\alpha$ TIF. The 100-fold difference in the efficiencies of formation of the $\mathrm{Cl}$ complex with the homeo box and the intact POU domain proteins can be accounted for by their difference in relative DNA-binding affinities. It is therefore likely that the homeo box contains most, if not all, of the Oct-1 determinants that mediate its protein-protein interactions in the $\mathrm{Cl}$ complex.

Although both the Oct-1 and Oct-2 POU domains may interact with $\alpha \mathrm{TIF} / \mathrm{Cl}$, Oct-1 has a 100 -fold greater affinity for this interaction (Kristie et al. 1989). A major part of this specificity appears to be due to differences in the amino acid sequence of the Oct- 1 and Oct- 2 homeo box subdomains (Stern et al. 1989). These regions differ in 8 of 63 positions, whereas the POU-specific boxes of these proteins are nearly identical (1 of 75 amino acids; Clerc et al. 1988; Sturm et al. 1988|. More directly, Stern and colleagues have shown that conversion of two amino acids in helix 2 of the Oct- 1 homeo box subdomain to those found in Oct-2 eliminated its ability to form the Cl-type complex efficiently (Stern et al. 1989).

The role of the Oct-1 POU-specific box and POU homeo box in the recognition of an octamer element

The high-resolution footprints of the Cl-type complexes formed with the POU and homeo box proteins on the $\alpha /$ IE element differ at the outer boundary of the octamer homolog. Several nucleotides $\left[5^{\prime}\right.$-ATGC-3' (top strand) and $5^{\prime}$-TGC- $3^{\prime}$ (bottom strand)] at the $5^{\prime}$ terminus of the octamer homolog are protected by the intact POU domain but not by the homeo box subregion (refer to Fig. $5 \mathrm{~B})$, while the remainder of the $\alpha /$ IE element is identically protected by the $\mathrm{C} 1$ complexes formed with either PA-POU or PA-homeo box. The same bases are specifically not protected by the complex formed with the homeo box protein as compared to the POU domain protein. This suggests that the POU-specific box of the POU domain functions to increase the affinity and specificity of the Oct-1 DNA-binding activity by direct interaction with the $5^{\prime}$ part of the octamer element. The recognition of specific DNA sequences by the POU-specific box is consistent with previous studies in which the POU-specific box was switched between the Oct-1 and Pit-1 proteins, leading to a change in the DNA-binding specificities of these proteins (Ingraham et al. 1990). The concept that the POU domain binds DNA with a bipartite specificity is additionally supported by the direct DNA-binding activity of a fusion protein that contains only the isolated Oct-1 POU-specific box /data not shown). Thus, the Oct-1 POU domain consists of two semi-independent DNA recognition domains that act synergistically. It is likely that all of the members of the POU domain family contain two binding specificities: one conferred by the POU-homeo box and another conferred by the POU-specific box. The sum of these yields the total sequence recognition specificity.

The relative orientation of the POU domain on the octamer site can be deduced from both the DNA sequences whose protection is assigned to the POU-specific box and the requirement that helix 2 of the homeo box subdomain be accessible for specific interactions with other proteins in the $\mathrm{Cl}$ complex. Only one orientation of the helix-turn-helix (helix 2-helix 3) of the homeo box is consistent with these two results (Fig. $6 \mathrm{~B}, \mathrm{C}$; for the structure of a homeo box protein, see Qian et al. 1989). In this arrangement, the DNA recognition helix 3 is positioned in the major groove, extending from helix 2, which must occupy the interface between the octamer site and the hypothetical $\alpha$ TIF-binding site. The POU-specific box at the amino terminus of helix 1 of the homeo box would be positioned near the $5^{\prime}$-ATGC- 3 ' sequences that are protected by the binding of this subdo- 
main. This assigned orientation is consistent with the recently determined crystal structure of a homeo box/ DNA complex (C. Pabo, pers. comm.).

The homeo box of Oct-1 must be a finely evolved structure. It must accommodate the DNA binding of the POU-specific box on one side and the $\alpha \mathrm{TIF} / \mathrm{Cl}$ factor on the other side. In addition, the homeo box can interact cooperatively in a homodimeric configuration upon binding to a site with inverted symmetry. This cooperativity is probably mediated by similar interactions to those that are involved in the cooperative interaction with $\alpha$ TIF. This range of possible protein-protein interactions probably accounts for the high degree of conservation in homeo box structures and may also explain the observation that all POU domain proteins share a conserved homeo box sequence that is a distinct subgroup of the large number of homeo box proteins.

\section{Materials and methods}

Production and purification of PA fusion proteins in $\mathrm{E}$. coli

DNA fragments encoding the Oct-1 POU domain |amino acids 270-441, \{Sturm et al. 1988)\}, the Oct-1 POU-specific box (amino acids 270-368), the Oct-1 homeo box (amino acids $368-441$ ), and the $\alpha$ TIF interactive domain (amino acids $1-412$ [Pellett et al. 1985)] were isolated and cloned to generate inframe fusions with the PA gene in pRIT2T (Pharmacial. E. coli N4830 strains, harboring the appropriate plasmids, were grown at $30^{\circ} \mathrm{C}$ to $\mathrm{OD}_{600}=0.8$ and induced to express the fusion products at $42^{\circ} \mathrm{C}$ for $1.5 \mathrm{hr}$. Extracts were prepared by freezing the harvested cells in $50 \mathrm{~mm}$ Tris at $\mathrm{pH} 8.0 / 10 \%$ (wt/vol) sucrose and thawing them in the presence of $0.5 \mathrm{mg} / \mathrm{ml}$ lysozyme. The cells were heat-shocked at $37^{\circ} \mathrm{C}$ for $10 \mathrm{~min}$, brought to 500 $\mathrm{mm} \mathrm{NaCl}$, and centrifuged at $200,000 \mathrm{~g}$ for $1 \mathrm{hr}$. The supernatants were brought to $50 \mathrm{~mm}$ Tris at $\mathrm{pH} 7.6 / 150 \mathrm{~mm}$ $\mathrm{NaCl} / 0.05 \%$ Tween-20, and the fusion products were purified on IgG-Sepharose (Pharmacia) according to the manufacturer's protocol for low $\mathrm{pH}$ elution. The purified fusion proteins were lyophylized briefly and brought to buffer A + $100 \mathrm{mM} \mathrm{KCl} \mathrm{[40}$ mM HEPES at pH 7.9/0.5 mm EDTA/0.5 mm DTT/20\% / $\mathrm{vol} /$ vol) glycerol]. Protein concentrations were determined by BioRad protein assay and by densitometric scanning of Coomassiestained SDS-PAGE-resolved proteins. The fusion proteins were judged to be $>70 \%$ homogeneous.

\section{Purification of baculovirus-expressed aTIF}

The expression and production of $\mathrm{S} 100$ extracts from AcNPV$\alpha$ TIF-infected SF9 cells was as described (Kristie et al. 1989). S100 extracts were applied to a DEAE-Sepharose CL6B column at $8 \mathrm{mg} / \mathrm{ml}$ in buffer $\mathrm{A}+100 \mathrm{mM} \mathrm{KCl}$. The column was washed with 10 column volumes of buffer $\mathrm{A}+100 \mathrm{mM} \mathrm{KCl}$, followed by successive steps of 5 column volumes each of buffer A containing $200 \mathrm{mM} \mathrm{KCl}, 350 \mathrm{~mm} \mathrm{KCl}$, and $500 \mathrm{~mm}$ $\mathrm{KCl}$. The $350 \mathrm{~mm} \mathrm{KCl} \mathrm{step} \mathrm{fractions} \mathrm{were} \mathrm{pooled,} \mathrm{dialyzed} \mathrm{to}$ buffer $\mathrm{A}+100 \mathrm{~mm} \mathrm{KCl}$, and reapplied to a high-resolution DEAE-Sepharose column. Adsorbed proteins were eluted with a linear $\mathrm{KCl}$ gradient of 200-400 mM. Protein concentrations were determined by Bio-Rad protein assay. Fractions were assayed for $\alpha$ TIF via SDS-PAGE and by gel mobility shift in the presence of HeLa nuclear extract. This $\alpha$ TIF preparation was judged to be $>90 \%$ homogeneous and contained no detectable $\mathrm{Cl}$ activity as determined by gel mobility shift assays in the presence of PA-POU protein.
SDS-PAGE purification and denaturation-renaturation of Oct-1 and aTIF proteins

Where indicated, proteins were further purified by preparative SDS-PAGE. IgG-Sepharose-purified PA fusion products or DEAE-purified $\alpha$ TIF protein fractions were resuspended in SDS-PAGE loading buffer, heated to $68^{\circ} \mathrm{C}$ for $10 \mathrm{~min}$, and resolved in a $12.5 \%$ polyacrylamide SDS-denaturing gel. The proteins were visualized by staining the gel with $0.25 \mathrm{M} \mathrm{KCl}$ as described (Hager and Burgess 1980). Gel slices containing the appropriate protein bands were excised from the gel, crushed in silated Dounce homogenizers, and incubated with elution buffer (Hager and Burgess 1980) $+100 \mu \mathrm{g} / \mathrm{ml}$ insulin for $12 \mathrm{hr}$ at $25^{\circ} \mathrm{C}$. The eluted proteins were precipitated with acetone, resuspended in $100 \mu \mathrm{l} \mathrm{HCl}$-guanidine denaturation buffer (Hager and Burgess 1980) $+100 \mu \mathrm{g} / \mathrm{ml}$ insulin, and dialyzed against buffer $\mathrm{A}+100 \mathrm{~mm} \mathrm{KCl}$ at $4^{\circ} \mathrm{C}$. Alternatively, the denatured proteins were diluted 100 -fold in buffer $\mathrm{A}+100 \mathrm{mM} \mathrm{KCl}$. The yield and purity of the renatured proteins were determined by SDS-PAGE. Renatured proteins were judged to be homogeneous preparations containing the purified protein and carrier insulin protein.

\section{Protein-DNA-binding assays}

HSV $\alpha 0$, wild-type, $5^{\prime} \mathrm{MT}$, and $3^{\prime} \mathrm{MT}$ DNA probes are equivalent to pRB608, $\alpha \mathrm{OH1}, \alpha \mathrm{H1}-5^{\prime} \mathrm{MT}$, and $\alpha \mathrm{OH} 1-3^{\prime} \mathrm{MT}$, respectively, and have been described (Kristie and Roizman 1987; Kristie et al. 1989). SF9 cell S100 extracts and octamer-depleted HeLa nuclear extracts were prepared as described previously (Kristie et al. 1989). Unless otherwise noted, DNA/protein-binding reactions contained $0.5 \mathrm{ng}(8.0$ fmoles $) \mathrm{HSV} \alpha 0$ DNA probe, 50- $1000 \mathrm{ng}$ poly[d(I-C)]/poly[d(I-C)], $10 \mathrm{mM}$ HEPES (pH 7.9), 0.5 mM EDTA, 25-75 mM KCl, $0.75 \mathrm{~mm}$ DTT, 4\% Ficoll 400, 300 $\mu \mathrm{g} / \mathrm{ml}$ bovine serum albumin, and the appropriate purified protein or chromatographic fraction in a total volume of $10 \mu \mathrm{l}$. Reactions were incubated at $30^{\circ} \mathrm{C}$ for $30 \mathrm{~min}$ and resolved in $4 \%$ nondenaturing polyacrylamide gels using $0.5 \times$ Tris-glycine electrophoresis buffer as described (Fried and Crothers 1981; Garner and Revzin 1981). Autoradiograms of dryed gels were scanned, where appropriate, on an LKB XL ultrodensitometer. For the determination of molecular mass values for the PAPOU and PA-homeo box proteins, increasing amounts of these proteins were added to a binding reaction containing either the HSV $\alpha$ or the consensus octamer [GCATGCAAAT (Falkner and Zachau 1984) $/$ DNA probes and $30 \mathrm{ng}$ poly[d(I-C)]/poly[d(IC)]. The protein-DNA complexes and free DNA were quantitated after electrophoresis by scanning the dryed gel mobility shift gel using a Molecular Dynamics phosphoimager. Molecular mass values for PA-POU were obtained at $50 \%$ bound DNA using the equation $\mathrm{kD}=$ (protein concentration at $50 \%$ saturation) - (concentration of bound DNA), where the DNA concentration was $6.7 \times 10^{-10} \mathrm{M}$. Values for PA-homeo box were extrapolated from those obtained at protein concentrations below $50 \%$ saturation. Values for the Cl-type complexes containing either PA-POU or PA-homeo box complexes were determined similarly by titration of the respective proteins in reactions containing $50 \mathrm{ng} \mathrm{PA}-\alpha \mathrm{TIF}$ and $2 \mu \mathrm{LE}-\mathrm{Clb}$ fraction.

\section{Chromatographic fractionation of the C1 factor}

S100 extracts were prepared from SF9 cells and applied to a DEAE-Sepharose CL6B column in buffer A $+100 \mathrm{~mm} \mathrm{KCl}$. The column was washed with 10 column volumes of buffer A $+100 \mathrm{mM} \mathrm{KCl}$, and the adsorbed proteins were eluted with successive steps of 5 column volumes each of buffer $\mathrm{A}+200$ $\mathrm{mM} \mathrm{KCl}, 350 \mathrm{mM} \mathrm{KCl}$, and $500 \mathrm{~mm} \mathrm{KCl}$. The $350 \mathrm{~mm} \mathrm{KCl}$ step 
fractions were pooled (DE-Cla) and reapplied to a high-resolution DEAE-Sepharose column. Bound proteins were eluted with a linear $\mathrm{KCl}$ gradient of $200-400 \mathrm{~mm}$. Fractions con taining $\mathrm{Cl}$ activity (DE-Clb) were diluted to buffer $\mathrm{A}+50$ $\mathrm{mM} \mathrm{KCl}$ and applied to a heparin-agarose column, equilibrated in buffer $\mathrm{A}+50 \mathrm{mM} \mathrm{KCl}$. The column was washed as above. The adsorbed proteins were eluted with a linear gradient of $50-150 \mathrm{mM} \mathrm{KCl}$ in buffer $\mathrm{A}$, followed by successive steps to $250 \mathrm{~mm} \mathrm{KCl}$ and $350 \mathrm{~mm} \mathrm{KCl}$. DE-Clb activity was loaded onto a single-stranded DNA-cellulose and a double-stranded DNA-cellulose column, equilibrated in buffer A $+50 \mathrm{~mm}$ $\mathrm{KCl}$. The columns were washed with 10 column volumes of buffer $\mathrm{A}+50 \mathrm{mM} \mathrm{KCl}$, and the proteins were eluted with successive steps of $100,250,350$, and $500 \mathrm{~mm} \mathrm{KCl}$. All fractions were assayed for $\mathrm{Cl}$ activity by gel mobility shift in the presence of PA-POU and PA- $\alpha$ TIF. Protein concentrations were determined by Bio-Rad protein assays. $\mathrm{KCl}$ concentrations were assayed by conductivity assays. Phosphatase treatment of $\mathrm{Cl}$ activity was done by incubation of the appropriate fractions from the heparin-agarose chromatography with potato acid phosphatase (Sigma) or alkaline phosphatase (Boehringer Mannheim) for $0.25 \mathrm{hr}$ at $30^{\circ} \mathrm{C}$ prior to the addition to the DNA-binding reaction.

\section{Protein affinity chromatography}

PA-q-POU, PA $-\alpha$ TIF, and PA were purified on IgG-Sepharose as described above. Then, $1.5 \mathrm{mg}$ of each purified protein was diluted to $10 \mathrm{ml}$ in $50 \mathrm{~mm}$ Tris at $\mathrm{pH} 7.6 / 150 \mathrm{~mm} \mathrm{NaCl} / 0.05 \%$ Tween-20. IgG-Sepharose $\{2 \mathrm{ml} /$ was added, and the slurry was mixed on a rotator at $4^{\circ} \mathrm{C}$ for $3 \mathrm{hr}$. The matrices were washed successively with buffer $\mathrm{A}+50 \mathrm{~mm} \mathrm{KCl}$, buffer $\mathrm{A}+50 \mathrm{~mm}$ $\mathrm{KCl}+100 \mu \mathrm{g} / \mathrm{ml}$ insulin, and buffer $\mathrm{A}+50 \mathrm{~mm} \mathrm{KCl}$. Cl fractions (DE-Clb) were batch-absorbed with $1 \mathrm{ml}$ of PA-POU or $1 \mathrm{ml} \mathrm{PA- \alpha TIF}$ matrix in buffer $\mathrm{A}+50 \mathrm{~mm} \mathrm{KCl}$ at $4^{\circ} \mathrm{C}$ for $2 \mathrm{hr}$. The matrices were poured into columns and washed with 3 column volumes each of buffer $\mathrm{A}+50 \mathrm{mM} \mathrm{KCl}, 150 \mathrm{mM} \mathrm{KCl}$, and $500 \mathrm{mM} \mathrm{KCl}$. $\mathrm{Cl}$ activity was assayed by gel mobility shift in the presence of PA-POU and PA- $\alpha$ TIF. Then $5 \mu \mathrm{g}$ baculovirus-expressed $\alpha$ TIF was chromatographed similarly on $1-\mathrm{ml}$ PA-POU and 1-ml PA columns. The elution of $\alpha$ TIF was monitored by gel mobility shift in the presence of PA-POU and $2 \mu \mathrm{l}$ $\mathrm{DE}-\mathrm{Cla}$ fraction or, alternatively, in the presence of $10 \mu \mathrm{g}$ of complete HeLa nuclear extract.

\section{Orthophenanthroline/Cu footprinting reactions}

Orthophenanthroline/ $\mathrm{Cu}$ footprinting reactions were done as described (Kuwabara and Sigman 1987; Kristie et al. 1989) except that the cleavage reactions were done at $4^{\circ} \mathrm{C}$. Autoradiographs of the dryed gels were analyzed by densitometry, and the limits of protection were determined in several independent experiments.

\section{UV-cross-linking reactions}

Body-labeled probes were prepared by polymerase chain reac-

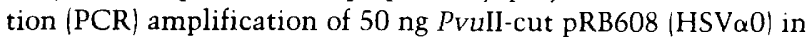
the presence of $200 \mu \mathrm{Ci}\left[\alpha^{-32} \mathrm{P}\right] \mathrm{dATP}, 200 \mu \mathrm{Ci}$ [ $\left.{ }^{32} \mathrm{P}\right] \mathrm{dCTP}, 5 \mu \mathrm{M}$ dATP, $5 \mu \mathrm{M} \mathrm{dCTP,} 200 \mu \mathrm{M}$ dGTP, $200 \mu \mathrm{M}$ dTTP or $200 \mu \mathrm{M}$ BrdU - triphosphate, $0.5 \mu \mathrm{M} \mathrm{M13}$ universal primer, and $0.5 \mu \mathrm{M}$ M13 reverse sequencing primer. PCR reaction products were digested with EcoRI and HindIII, and the DNA probe was isolated from a $6 \%$ polyacrylamide gel as described (Maniatis et al. 1982). DNA-protein-binding reactions, containing SDS-PAGEpurified proteins, were scaled up threefold, incubated at $30^{\circ} \mathrm{C}$ for $30 \mathrm{~min}$, and irradiated with a fotodyne UV lamp (254 nm) at $4000 \mu \mathrm{W} / \mathrm{cm}^{2}$ for $30 \mathrm{~min}$ in an ice-water bath. The reactions were brought to $7.5 \mathrm{mM} \mathrm{CaCl}_{2}$ and digested with $10 \mu \mathrm{g}$ DNase 1 and 5 units micrococcal nuclease for $30 \mathrm{~min}$ at $37^{\circ} \mathrm{C}$. Nucleasedigested reaction products were resolved in a $12.5 \%$ SDS-denaturing gel and transferred to nitrocellulose in the presence of $0.1 \%$ SDS. For Western blot analysis of radiolabeled proteins, the nitrocellulose was cut into the appropriate strips after autoradiography and blotted with anti- $\alpha$ TIF sera (gifts of J.L.C. McKnight and S. McKnight).

\section{Acknowledgments}

This work is dedicated to the memory of Mrs. Betty J. Kristie whose unconditional personal support will be greatly missed. We thank J.L.C. McKnight and S. McKnight for $\alpha$ TIF antibody; J.L.C. McKnight and J. LeBowitz for helpful discussions; C. Pabo for the discussion of results prior to publication, A. Gil, R. Clerc, M. Timmers, R. Meyers, D. Fisher, P. Sengupta, and J. Parvin for their critical review of this manuscript; S. Jamison and B. Mulrenin for expert technical assistance; M. Siafaca for her ever-present assistance; and the members of the Sharp laboratory for their continual interest. T.M.K. was a J.C. Childs Memorial Fund Fellow (project no. 61-767) during the time that the predominant portion of this work was done and is a Leukemia Society of America Special Fellow. This work was supported by U.S. Public Health Service grant PO1-CA42063, partially by Cancer Center Support (core) grant P30-CA1405l from the National Institutes of Health, and by a cooperative agreement (CDR-8803014) from the National Science Foundation to P.A.S.

The publication costs of this article were defrayed in part by payment of page charges. This article must therefore be hereby marked "advertisement" in accordance with 18 USC section 1734 solely to indicate this fact.

\section{References}

Ares, M. Jr., J. Chung, L. Giglio, and A.M. Weiner. 1987. Distinct factors with SPI and NFA specificities bind to adjacent functional elements of the human U2 snRNA gene enhancer. Genes Dev. 1: 808-817.

Bark, C., P. Weller, J. Zabeilski, L. Janson, and U. Petterson. 1987. A distant enhancer element is required for transcription of a U6 RNA gene. Nature 328: 356-362.

Batterson, W. and B. Roizman. 1983. Characterization of the herpes simplex virion-associated factor responsible for the induction of $\alpha$ genes. J. Virol. 46: 371-377.

Bzik, D.J. and C.M. Preston. 1986. Analysis of DNA sequences which regulate the transcription of herpes simplex virus immediate early gene 3: DNA sequences required for enhancer-like activity and response to trans-activation by a virion polypeptide. Nucleic Acids Res. 14: 929-943.

Campbell, M.E.M., J.W. Palfreyman, and C.M. Preston. 1984. Identification of herpes simplex virus DNA sequences which encode a trans-acting polypeptide responsible for stimulation of immediate early transcription. \%. Mol. Biol. 180: $1-19$.

Carbon, P., S. Murgo, J.-P. Ebel, A. Krol, G. Tebb, and I.W. Mattaj. 1987. A common octamer motif binding protein is involved in the transcription of the U6 snRNA by RNA polymerase III and U2 snRNA by RNA polymerase II. Cell 51: $71-79$.

Clerc, R.G., L.M. Corcoran, J.H. LeBowitz, D. Baltimore, and P.A. Sharp. 1988. The B-cell-specific Oct-2 protein contains POU box- and homeo box-type domains. Genes Dev. 2: $1570-1581$. 
Desplan, C., J. Theis, and P.H. O'Farrell. 1988. The sequence specificity of homeodomain-DNA interaction. Cell 54: $1081-1090$.

Falkner, F.B. and H.G. Zachau. 1984. Correct initiation of an immunoglobulin $\kappa$ gene requires an upstream fragment containing conserved sequence elements. Nature 310: 71-74.

Fletcher, C., N. Heintz, and R.G. Roeder. 1987. Purification and characterization of OTF-1, a transcription factor regulating cell cycle expression of a human histone $\mathrm{H} 2 \mathrm{~b}$ gene. Cell 51: $773-781$.

Fried, M. and D. Crothers. 1981. Equilibria and kinetics of lac repressor-operator interactions by polyacrylamide gel electrophoresis. Nucleic Acids Res. 9: 6505-6525.

Friedman, A.D., S.J. Triezenberg, and S.L. McKnight. 1988. Expression of a truncated viral trans-activator selectively impedes lytic infection by its cognate virus. Nature 335: 452454.

Gaffney, D.F., J. McLauchlan, J.L. Whitton, and J.B. Clements. 1985. A modular system for the assay of transcription regulatory signals: The sequence TAATGARAT is required for herpes simplex virus immediate early gene activation. $\mathrm{Nu}$ cleic Acids Res. 13: 7874-7862.

Garcia-Blanco, M., R.G. Clerc, and P.A. Sharp. 1989. The DNAbinding homeo domain of the Oct-2 protein. Genes Dev. 3: $739-745$.

Garner, M.M. and A. Revzin. 1981. A gel electrophoresis method for quantifying the binding of proteins to specific DNA regions. Nucleic Acids Res. 9: 3047-3060.

Gerster, T. and R.G. Roeder. 1988. A herpesvirus trans-acting protein interacts with transcription factor OTF- 1 and other cellular proteins. Proc. Nat1. Acad. Sci. 85: 6347-6351

Gerster, T., C.-G. Balmaceda, and R.G. Roeder. 1990. The cellspecific octamer transcription factor OTF-2 has two domains required for the activation of transcription. EMBO /. 9: $1635-1643$.

Greaves, R.F. and P. O'Hare. 1990. Structural requirements in the herpes simplex virus type 1 transactivator Vmw65 for interaction with the cellular octamer-binding protein and target TAATGARAT sequences. /. Virol. 64: 2716-2724

Hager, D.A. and R.R. Burgess. 1980. Elution of proteins from sodium dodecyl sulfate-polyacrylamide gels, removal of sodium dodecyl sulfate, and renaturation of enzymatic activity: Results with sigma subunits of Escherichia coli RNA polymerase, wheat germ DNA topoisomerase, and other enzymes. Anal. Biochem. 109: 76-86.

He, X., M.N. Treacy, D.M. Simmons, H.A. Ingraham, L.W. Swanson, and M.G. Rosenfeld. 1989. Expression of a large family of POU-domain regulatory genes in mammalian brain development. Nature 340: 35-42.

Herr, W., R.A. Sturm, R.G. Clerc, L.M. Corcoran, D. Baltimore, P.A. Sharp, H.A. Ingraham, M.G. Rosenfeld, M. Finney, G. Ruvkin, and H.R. Horvitz. 1988. The POU domain: A large conserved region in the mammalian pit-1, oct-1, oct-2, and Caenorhabditis elegans unc-86 gene products. Genes Dev. 2: $1513-1516$.

Hoey, T. and M. Levine. 1988. Drosophila homeobox proteins recognize similar sequences in Drosophila. Nature 332: $858-861$.

Ingraham, H.A., S.E. Flynn, J.W. Voss, V.R. Albert, M.S. Kapiloff, L. Wilson, and M.G. Rosenfeld. 1990. The POU-specific domain of Pit-l is essential for sequence-specific, high affinity DNA binding and DNA-dependent Pit-1-Pit-1 interactions. Cell 61: 1021-1033.

Johnson, W.A. and J.A. Hirsch. 1990. Binding of a Drosophila POU-domain protein to a sequence element regulating gene expression in specific dopaminergic neurons. Nature
342: $467-470$.

Jordan, S.R. and C.O. Pabo. 1988. Structure of the lambda complex at $2.5 \mathrm{~A}$ resolution: Details of the repressor-operator interactions. Science 242: 893-899.

Ko, H.-S., P. Fast, W. McBride, and L.M. Staudt. 1988. A human protein specific for the immunoglobulin octamer DNA motif contains a functional homeobox domain. Cell 55: $135-144$.

Kristic, T.M. and B. Roizman. 1984. Separation of sequences defining basal expression from those conferring $\alpha$ gene recognition within the regulatory domains of herpes simplex virus 1 a genes. Proc. Natl. Acad. Sci. 81: 4065-4069.

1987. Host cell proteins bind to the cis-acting site required for virion-mediated induction of herpes simplex virus $1 \alpha$ genes. Proc. Natl. Acad. Sci. 84: 71-75.

-1988. Differentiation of DNA contact points of host proteins binding at the cis site for virion-mediated induction of $\alpha$ genes of herpes simplex virus 1. I. Virol. 62: 1145-1157.

Kristie, T.M., J.H. LeBowitz, and P.A. Sharp. 1989. The octamer-binding proteins form multi-protein-DNA complexes with the HSV $\alpha$ TIF regulatory protein. EMBO I. 8: 42294238 .

Kuwabara, M.D. and D.S. Sigman. 1987. Footprinting DNAprotein complexes in situ following gel retardation assays using 1,10 phenanthroline-copper ion: Escherichia coli RNA polymerase-lac promoter complexes. Biochemistry 26: $7234-7238$.

La Bella, F., H.L. Sive, R.G. Roeder, and N. Heintz. 1988. Cellcycle regulation of a human histone $\mathrm{H} 2 \mathrm{~b}$ gene is mediated by the H2b subtype-specific consensus element. Genes Dev. 2: $32-39$.

Laughon, A. and M.P. Scott. 1984. Sequence of a Drosophila segmentation gene: Protein homology with the DNAbinding proteins. Nature 310: $25-31$.

LeBowitz, J.H., T. Kobayashi, L. Staudt, D. Baltimore, and P.A. Sharp. 1988. Octamer-binding protein from B or HeLa cells stimulate transcription of the immunoglobulin heavy-chain promoter in vitro. Genes Dev. 2: 1227-1237.

LeBowitz, I.H., R.G. Clerc, M. Brenowitz, and P.A. Sharp. 1989. The Oct-2 protein binds cooperatively to adjacent octamer sites. Genes Dev. 3: 1625-1638.

Lenardo, M.J., L. Staudt, P. Robbins, A. Kuang, R.C. Mulligan, and D. Baltimore. 1989. Repression of the IgH enhancer in teratocarcinoma cells associated with a novel octamer factor. Science 243: 544-546.

Mackem, S. and B. Roizman. 1980. Regulation of herpesvirus macromolecular synthesis: Transcription-initiation sites and domains of a genes. Proc. Natl. Acad. Sci. 77: 71227126 .

1982a. Regulation of $\alpha$ genes of herpes simplex virus: The $\alpha 27$ promoter-thymidine kinase chimeric gene is positively regulated in converted L cells. I. Virol. 43: 10151023.

- 1982b. Structural features of the $\alpha$ gene 4,0 , and 27 promoter-regulatory sequences which confer $\alpha$ regulation on chimeric thymidine kinase genes. J. Virol. 44: 939-949.

. 1982c. Differentiation between $\alpha$ promoter and regulator regions of herpes simplex virus I: The functional domains and sequence of a movable $\alpha$ regulator. Proc. Natl. Acad. Sci. 79: 4917-4921.

Maniatis, T., E.F. Fritsch, and J. Sambrook. 1982. Molecular cloning: A laboratory manual. Cold Spring Harbor Laboratory, Cold Spring Harbor, New York.

Marsden, H.S., M.E.M. Campbell, L. Haarr, M.C. Frame, D.S Parris, M. Murphy, R.G. Hope, M.T. Muller, and C.M. Preston. 1987. The $65,000-\mathrm{Mr}$ DNA-binding and virion 
trans-inducing proteins of herpes simplex virus type 1.1 . Virol. 61: 2428-2437.

Maxam, A. and W. Gilbert. 1980. Sequencing end-labeled DNA with base-specific chemical cleavages. Methods Enzymol. 65: 499-560.

McGinnis, W., R.L. Garber, J. Wirz, A. Kuroiwa, and W.J. Gehring. 1984. A homologous protein-coding sequence in Drosophila homeotic genes and its conservation in other metazoans. Cell 37: 403-408.

McKnight, J.L.C., T.M. Kristie, S. Silver, P.E. Pellett, G. Mavromara-Nazos, G. Campadelli-Fiume, M. Arsenakis, and B. Roizman. 1986. Regulation of herpes simplex virus 1 gene expression: The effect of genomic enviroments and its implication for model systems. Cancer Cells 4: 163-173.

McKnight, J.L.C., T.M. Kristie, and B. Roizman. 1987. The binding of the virion protein mediating $\alpha$ gene induction in herpes simplex virus 1 infected cells to its cis site requires cellular proteins. Proc. Natl. Acad. Sci. 84: 7061-7065.

Mizushima-Sugano, J. and R.G. Roeder. 1986. Cell-type-specific transcription of an immunoglobulin $\kappa$ light chain in vitro. Proc. Natl. Acad. Sci. 83: 8511-8515.

Muller, M., M. Affolter, L. Werner, G. Otting, K. Wuthrich, and W.J. Gehring. 1988. Isolation and sequence-specific DNA binding of the Antennapedia homeodomain. EMBO $/$. 7: 4299-4304.

Muller, M.M., S. Ruppert, W. Schaffner, and P. Matthias. 1988. A cloned octamer transcription factor stimulates transcription from lymphoid-specific promoters in non-B cells. $\mathrm{Na}$. ture 336: 544-551.

Muller-Immergluck, M.M., W. Schaffner, and P. Matthias. 1990. Transcription factor Oct-2A contains functionally redundant activating domains and works selectively from a promoter but not from a remote enhancer position in nonlymphoid (HeLa) cells. EMBO J. 9: 1625-1634.

Murphy, S., C. Di Leigro, and M. Melli. 1987. The in vitro transcription of the 7SK RNA gene by RNA polymerase III is dependent only on the presence of an upstream promoter. Cell 51: 81-87.

O'Hare, P. and C.R. Goding. 1988. Herpes simplex virus regulatory elements and the immunoglobulin octamer domain bind a common factor and are both targets for virus transactivation. Cell 52: 435-445.

O'Neill, E.A. and T.J. Kelly. 1988. Purification and characterization of nuclear factor III forigin initiation factor Cl. Sequence-specific DNA binding protein required for efficient initiation of adenovirus DNA replication. I. Biol. Chem. 263: 934-937.

Otting, G., Y.-Q. Qian, M. Muller, M. Affolter, W. Gehring, and K. Wuthrich. 1988. Secondary structure determination for the Antennapedia homeodomain by nuclear magnetic resonance and evidence for a helix-turn-helix motif. EMBO /. 7: 4305-4309.

Pellett, P.E., J.L.C. McKnight, F.J. Jenkins, and B. Roizman. 1985. Nucleotide sequence and predicted amino acid sequence of a protein encoded in a small herpes simplex virus DNA fragment capable of trans-inducing a genes. Proc. Natl. Acad. Sci. 82: 5870-5874.

Poellinger, L., B.K. Yoza, and R.G. Roeder. 1989. Functional cooperativity between protein molecules bound at two distinct sequence elements of the immunoglobulin heavychain promoter. Nature 337: 573-576.

Post, L.E., S. Mackem, and B. Roizman. 1981. The regulation of $\alpha$ genes of herpes simplex virus: Expression of chimeric genes produced by fusion of thymidine kinase with $\alpha$ gene promoters. Cell: 24: 555-565.

Preston, C.M., M.C. Frame, and M.E.M. Campbell. 1988. A complex formed between cell components and an HSV structural polypeptide binds to a viral immediate early gene regulatory DNA sequence. Cell 52: 425-434.

Pruijn, G.J.M., W. van Driel, and P.C. van der Vliet. 1986. Nuclear factor III, a novel sequence-specific DNA binding protein from HeLa cells stimulation adenovirus DNA replication. Nature 322: 656-659.

Pruijn, G.J.M., W. van Driel, T. van Miltenburg, and P.C. van der Vliet. 1987. Promoter and enhancer elements containing a conserved sequence motif are recognized by nuclear factor III, a protein stimulating adenovirus DNA replication. EMBO \%. 6: $3771-3778$.

Qian, Y.Q., M. Billeter, M. Muller, W.J. Gehring, and K. Wuthrich. 1989. The structure of the Antennapedia homeodomain determined by NMR spectroscopy in solution: Comparison with prokaryotic repressors. Cell 59: 573-580.

Roizman, B. and D. Furlong. 1974. The replication of herpesviruses. In Comprehensive virology led. $\mathrm{H}$. Fraenkel-Conrat and R.R. Wagner), pp. 299-403. Plenum Press, New York.

Scheidereit, C., A. Heguy, and R.G. Roeder, 1987. Identification and purification of a human lymphoid-specific octamerbinding protein $|\mathrm{OTF}-2|$ that activates transcription of an immunoglobulin promoter in vitro. Cell 51: 783-793.

Scholer, H.R., R. Balling, A.K. Hatzopoulos, N. Suzuki, and P. Gruss. 1989. Octamer binding proteins confer transcriptional activity in early mouse embryogenesis. EMBO $J$. 8: $2551-2557$.

Scholer, H.R., A.K. Hatzopoulos, R. Balling, N. Suzuki, and P. Gruss. 1989. A family of octamer-specific proteins present during mouse embryogenesis: Evidence for germline-specific expression of an Oct factor. EMBO /. 8: 2543-2550.

Schreiber, E., P. Matthias, M.M. Muller, and W. Schaffner. 1988. Identification of a novel specific octamer binding protein $|\mathrm{OTF}-2 \mathrm{~B}|$ by proteolytic clipping bandshift assay (PCBA). EMBO 1. 7: 4221-4229.

Scott, M.P., J.W. Tam Kun, and G.W. Hartzell III. 1989. The structure and function of the homeodomain. BBA Rev. Cancer 989: 25-49.

Siebenlist, U., R.B. Simpson, and W. Gilbert. 1980. E. coli RNA polymerase interacts homologously with two different promoters. Cell 20: 269-281.

Singh, H., R. Sen, D. Baltimore, and P. Sharp. 1986. A nuclear factor that binds a conserved sequence motif in transcriptional control elements of immunoglobulin genes. Nature 319: $154-158$.

Sive, H.L., N. Heintz, and R.G. Roeder. 1986. Multiple sequence elements are required for maximal in vitro transcription of a human histon H2B gene. Mol. Cell. Biol. 6: $3329-3340$.

Staudt, L.M., H. Singh, R. Sen, T. Wirth, P.A. Sharp, and D. Baltimore. 1986. A lymphoid-specific protein binding to the octamer motif of immunoglobulin genes. Nature 323: 640643

Stern, S., M. Tanaka, and W. Herr. 1989. The Oct-1 homoeodomain directs formation of a multiprotein-DNA complex with the HSV transactivator VP16. Nature 341: 624-630.

Sturm, R.A. and W. Herr. 1988. The POU-domain is a bipartite DNA binding structure. Nature 336: 601-604.

Sturm, R.A., G. Das, and W. Herr. 1988. The ubiquitous octamer-binding protein Oct- 1 contains a POU domain with a homeo box subdomain. Genes Dev. 2: 1582-1599.

Thali, M., M.M. Muller, M. DeLorenzi, P. Matthias, and M. Bienz. 1988. Drosophila homoeotic genes encode transcriptional activators similar to mammalian OTF-2. Nature 336: $598-600$.

Triezenberg, S.I., R.C. Kingsbury, and S.L. McKnight. 1988. 
Functional dissection of VP16, the trans-activator of herpes simplex virus immediate early gene expression. Genes Dev. 2: $718-729$.

Verrijzer, C.P., A.J. Kal, and P.C. van der Vliet. 1990. The DNA binding domain (POU domain) of transcription factor Oct-1 suffices for stimulation of DNA replication. EMBO $\%$ 9: $1883-1888$.

Werstuck, G. and J.P. Capone. 1989. Identification of a domain of the herpes simplex virus trans-activator Vmw65 required for protein-DNA complex formation through the use of protein A fusion proteins. J. Virol. 63: 5509-5513.

Wirth, T., L. Staudt, and D. Baltimore. 1987. An octamer oligonucleotide upstream of a TATA element is sufficient for lymphoid-specific promoter activity. Nature 329: 174-177.

\section{Note added in proof}

We would like to note that C.P. Verrijzer, A.J. Kal, and C. van der Vliet have come to similar conclusions with regard to the sequence-specific interactions of the POU-specific box of the Oct-1 protein (Verrijzer et al., Genes \&) Dev. 4: 1964-1974, 1990). 


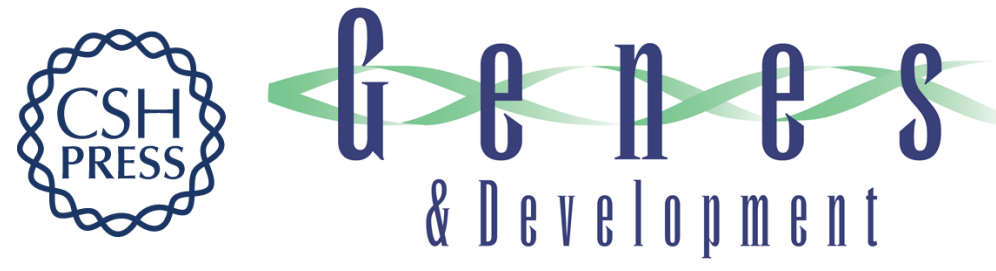

\section{Interactions of the Oct-1 POU subdomains with specific DNA sequences and with the HSV alpha-trans-activator protein.}

T M Kristie and P A Sharp

Genes Dev. 1990, 4:

Access the most recent version at doi:10.1101/gad.4.12b.2383

References This article cites 77 articles, 27 of which can be accessed free at:

http://genesdev.cshlp.org/content/4/12b/2383.full.html\#ref-list-1

License

Email Alerting

Service

Receive free email alerts when new articles cite this article - sign up in the box at the top right corner of the article or click here.

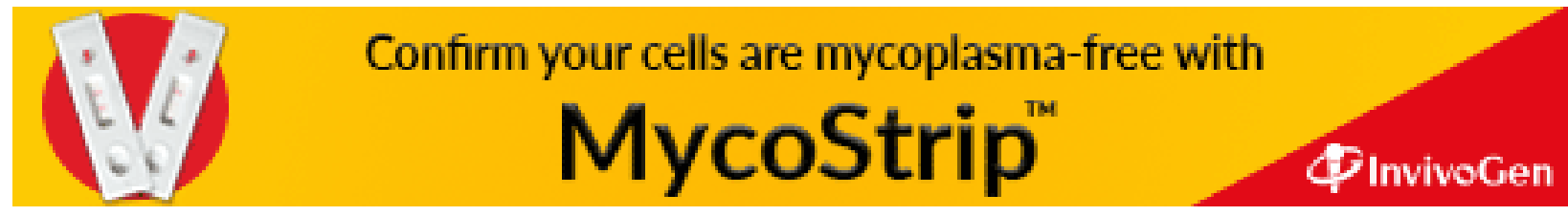

